Atmos. Chem. Phys., 18, 18101-18121, 2018

https://doi.org/10.5194/acp-18-18101-2018

(C) Author(s) 2018. This work is distributed under

the Creative Commons Attribution 4.0 License.

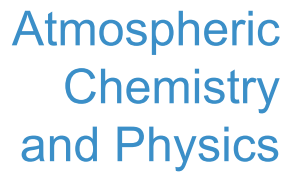

(c) (i)

\title{
Chemical composition of isoprene SOA under acidic and non-acidic conditions: effect of relative humidity
}

\author{
Klara Nestorowicz ${ }^{1}$, Mohammed Jaoui ${ }^{2}$, Krzysztof Jan Rudzinski ${ }^{1}$, Michael Lewandowski ${ }^{2}$, Tadeusz E. Kleindienst ${ }^{2}$, \\ Grzegorz Spólnik $^{3}$, Witold Danikiewicz ${ }^{3}$, and Rafal Szmigielski ${ }^{1}$ \\ ${ }^{1}$ Environmental Chemistry Group, Institute of Physical Chemistry Polish Academy of Sciences, 01-224 Warsaw, Poland \\ ${ }^{2}$ US Environmental Protection Agency, 109 T.W. Alexander Drive, RTP, NC 27711, USA \\ ${ }^{3}$ Mass Spectrometry Group, Institute of Organic Chemistry, Polish Academy of Science, 01-224 Warsaw, Poland
}

Correspondence: Rafal Szmigielski (ralf@ichf.edu.pl) and Mohammed Jaoui (jaoui.mohammed@epa.gov)

Received: 13 March 2018 - Discussion started: 19 March 2018

Revised: 27 November 2018 - Accepted: 29 November 2018 - Published: 20 December 2018

\begin{abstract}
The effect of acidity and relative humidity on bulk isoprene aerosol parameters has been investigated in several studies; however, few measurements have been conducted on individual aerosol compounds. The focus of this study has been the examination of the effect of acidity and relative humidity on secondary organic aerosol (SOA) chemical composition from isoprene photooxidation in the presence of nitrogen oxide $\left(\mathrm{NO}_{x}\right)$. A detailed characterization of SOA at the molecular level was also investigated. Experiments were conducted in a $14.5 \mathrm{~m}^{3} \mathrm{smog}$ chamber operated in flow mode. Based on a detailed analysis of mass spectra obtained from gas chromatography-mass spectrometry of silylated derivatives in electron impact and chemical ionization modes, ultra-high performance liquid chromatography/electrospray ionization/time-of-flight highresolution mass spectrometry, and collision-induced dissociation in the negative ionization modes, we characterized not only typical isoprene products but also new oxygenated compounds. A series of nitroxy-organosulfates (NOSs) were tentatively identified on the basis of high-resolution mass spectra. Under acidic conditions, the major identified compounds include 2-methyltetrols (2MT), 2-methylglyceric acid (2mGA), and 2MT-OS. Other products identified include epoxydiols, mono- and dicarboxylic acids, other organic sulfates, and nitroxy- and nitrosoxy-OS. The contribution of SOA products from isoprene oxidation to $\mathrm{PM}_{2.5}$ was investigated by analyzing ambient aerosol collected at rural sites in Poland. Methyltetrols, $2 \mathrm{mGA}$, and several organosulfates and nitroxy-OS were detected in both the field and laboratory samples. The influence of relative humidity on SOA
\end{abstract}

formation was modest in non-acidic-seed experiments and stronger under acidic seed aerosol. Total secondary organic carbon decreased with increasing relative humidity under both acidic and non-acidic conditions. While the yields of some of the specific organic compounds decreased with increasing relative humidity, others varied in an indeterminate manner from changes in the relative humidity.

\section{Introduction}

Secondary organic aerosol (SOA) is formed through complex physicochemical reactions of volatile organic compounds which are emitted into the atmosphere from biogenic and anthropogenic sources and can constitute a substantial portion of the continental aerosol mass (Goldstein and Galbally, 2007; Hallquist et al., 2009). Of the volatile organic compounds, isoprene is the most abundant non-methane hydrocarbon emitted to the atmosphere (Guenther et al., 1995, 2006). Although the SOA yield of isoprene tends to be low, its sizable emissions can contribute to a high organic aerosol loading, making it one of the most studied compounds for aerosol formation (Guenther et al., 1995; Henze and Seinfeld, 2006; Fu et al., 2008; Carlton et al., 2009; Hallquist et al., 2009). The primary removal mechanism for isoprene is by gas-phase reactions with hydroxyl radicals $(\mathrm{OH})$; nitrate radicals; and, to a lesser extent, ozone. These processes result in the formation of gas and aerosol products including numerous oxidized SOA components. Aerosol species previously reported include 2-methyltetrols, 2-methylglyceric 
acid, $\mathrm{C}_{5}$-alkene triols, and organosulfates (i.e., Edney et al., 2005; Surratt et al., 2007a, 2010; Riva et al., 2016; Spolnik et al., 2018). While many of these are formed through multiphase chemistry (e.g., isoprene epoxydiol (IEPOX) channel), we cannot exclude their gas-phase formation at least for 2-methyltetrols, probably in part through re-evaporation processes (Issacman-VanWertz et al., 2016), and for 2methylglyceric acid, as these compounds have been linked to gas-phase reaction products from the oxidation of isoprene (Kleindienst et al., 2009) and in ambient $\mathrm{PM}_{2.5}$ (Xie at al., 2014). Moreover, these compounds have been identified in ambient $\mathrm{PM}_{2.5}$ in several places around the world, and SOA from isoprene often accounts for $20 \%-50 \%$ of the overall SOA budget (Claeys et al., 2004a; Wang et al., 2005; Henze and Seinfeld, 2006; Kroll et al., 2006; Surratt et al., 2006; Hoyle et al., 2007).

An enhancement of isoprene (ISO)-SOA yields is controlled by various factors including $\mathrm{NO}_{x}$ concentration (Kroll et al., 2006; Chan et al., 2010; Surratt et al., 2006, 2010) and the acidity of preexisting aerosol (Jang et al., 2002; Czoschke et al., 2003; Edney et al., 2005; Kleindienst et al., 2006; Surratt et al., 2007a, 2010; Jaoui et al., 2010; Szmigielski et al., 2010). The strength of the acidity depends on the aerosol liquid water content and the relative humidity (RH; Nguyen et al., 2011; Zhang et al., 2011; Lewandowski et al., 2015; Wong et al., 2015), which are coupled. Smog chamber experiments have revealed that the yield of isoprene SOA increases under acidic conditions through an enhanced formation of isoprene-derived oxygenates by acid-catalyzed reactions (Surratt et al., 2007b, 2008, 2010; Gomez-Gonzalez et al., 2008; Offenberg et al., 2009). By one mechanism, isoprene reactions with $\mathrm{OH}$ under low- or high- $\mathrm{NO}_{x}$ conditions can form epoxydiols (IEPOX) in high yields followed by their uptake by SOA and subsequent acid-catalyzed particle reactions (Paulot et al., 2009; Surratt et al., 2010; Lin et al., 2013; Budisulistiorini et al., 2015; Rattanavaraha et al., 2016; Gaston et al., 2014a, b; Riedel et al., 2015; Zhang et al., 2018). However, this type of multiphase chemistry following the uptake of IEPOX can be highly dependent on the aerosol-phase state and the presence of aerosol coatings from viscous SOA constituents (Zhang et al., 2018). Such coatings can cause a substantial diffusion barrier to the availability to an acidic core.

Atmospheric organosulfates are another class of organic compounds formed from atmospheric reactions of various precursors, including isoprene, and have been identified as components of ambient particulate matter (PM; Surratt et al., 2008; Froyd et al., 2010; Stone et al., 2012; Tolocka and Turpin, 2012). The most common isoprene organosulfates have been identified both in smog chamber experiments and in field studies (Surratt et al., 2007a, 2008, 2010; Gomez-Gonzalez et al., 2008; Shalamzari et al., 2013; Tao et al., 2014; Hettiyadura et al., 2015; Szmigielski, 2016; Spolnik et al., 2018). For many of these polar oxygenated compounds, chemical structures, mass spectrometry (MS) frag- mentation patterns, and formation mechanisms have been tentatively proposed (Surratt et al., 2007a, b; 2008, 2010; Gomez-Gonzalez et al., 2008; Zhang et al., 2011; Shalamzari et al., 2013; Schindelka et al., 2013; Nguyen et al., 2014; Tao et al., 2014; Hettiyadura et al., 2015; Riva et al., 2016; Spolnik et al., 2018). The commonly detected components of isoprene SOA attributed to processing of isoprene oxidation products (e.g., IEPOX, methacrolein, and methyl vinyl ketone) have the reported molecular weights (MWs) of 154,156, 184, 198, 200,212, 214, 216, 260, and 334 (Surratt et al., 2007b, 2008, 2010; Gomez-Gonzalez et al., 2008; Kristensen et al., 2011; Zhang et al., 2011; Shalamzari et al., 2013; Schindelka et al., 2013; Nguyen et al., 2014; Hettiyadura et al., 2015; Riva et al., 2016). The mechanisms of OS formation were proposed for the conditions of either acidified or non-acidified sulfate aerosol seeds (e.g., 2methyltetrol organosulfates proposed by Surratt et al., 2007a, and Riva et al., 2016). Whereas Kleindienst et al. (2006) reported the formation of highly oxygenated products through $\mathrm{OH}$ radical oxidation, Riva et al. (2016) proposed an alternative route through acid-catalyzed oxidation by organic peroxides. Isoprene organosulfates were also reported to occur in the aqueous phase through the photooxidation or dark reactions of isoprene in aqueous solutions containing sulfate and sulfite moieties (Rudzinski et al., 2004, 2009; Noziere et al., 2010). A detailed mechanism of this transformation has been tentatively proposed based on chain reactions propagated by sulfate and sulfite radical anions (Rudzinski et al., 2009) and confirmed by mass spectrometric studies (Szmigielski, 2016). The acid-catalyzed formation of 2-methyltetrols has also been suggested in aqueous-phase oxidation of isoprene with $\mathrm{H}_{2} \mathrm{O}_{2}$ (Claeys et al., 2004b).

To date, few smog chamber studies have examined the effect of relative humidity on ISO-SOA formation (Dommen et al., 2006; Nguyen et al., 2011; Zhang et al., 2011; Lewandowski et al., 2015; Wong et al., 2015; Riva et al., 2016). However, the impact of relative humidity may be an important parameter, in that it may influence the mechanism of SOA formation and hence the chemical composition, physical properties, and yield of isoprene SOA (Vasconcelos et al., 1994; Poulain et al., 2010; Guo et al., 2014). The chamber studies conducted by Dommen et al. (2006) and Nguyen et al. (2011) showed a negligible effect of relative humidity on the SOA yield from the photooxidation of isoprene in the absence of sulfate aerosol. Other studies suggested that ISO-SOA formation yields under high-NO $\mathrm{NO}_{x}$ conditions with acidified and non-acidified sulfate aerosol decreased with an increase in relative humidity while simultaneously the yield of organosulfates was enhanced (Zhang et al., 2011; Lewandowski et al., 2015). The latter observation can be explained by transformation of isoprene propagated by sulfate/sulfite radical anions in the aqueous particle phase or on the aqueous surface of aerosol particles (Zhang et al., 2011; Rudzinski et al., 2016; Szmigielski, 2016). The results obtained from the chamber experiments have been in agree- 
ment with recent model approaches when reactive uptake to aqueous aerosol is used rather than a reversible partitioning approach (Pye et al., 2013; Marais et al., 2016). A recent study conducted in our laboratory focused on the effects of relative humidity on secondary organic carbon (SOC) formation from isoprene photooxidation in the presence of $\mathrm{NO}_{x}$ (Lewandowski et al., 2015). The study indicated that relative humidity can have a profound effect on the acid-derived enhancement of isoprene SOC, while an increasing content of aerosol liquid water suppressed the level of enhancement.

The focus of the present study is to investigate at a molecular level the role of relative humidity on the chemical composition of isoprene SOA obtained under acidic and nonacidic conditions. Organosulfate compounds were analyzed using liquid chromatography-mass spectrometry (LC-MS) measurements (Szmigielski, 2016; Rudzinski et al., 2009; Darer et al., 2011; Surratt et al., 2007a), while non-sulfate oxygenated compounds were examined using derivatization followed by gas chromatography-mass spectrometry (GCMS) analysis (Jaoui et al., 2004). Here we explored the $\mathrm{RH}$ effect of a wide range of isoprene polar oxygenated products, including 2-methyltetrols, 2-methylglyceric acid, IEPOX, organosulfates), nitroxy-organosulfates (NOSs), and other selected oxygenates in the presence of acidified and non-acidified sulfate aerosol. In addition, a chemical analysis of $\mathrm{PM}_{2.5}$ field samples has been conducted to assess the possible relationship between the laboratory findings and their role in ambient SOA formation.

\section{Experimental methods}

\subsection{Smog chamber experiments}

Chamber experiments were conducted in a $14.5 \mathrm{~m}^{3}$ stainlesssteel, fixed-volume chamber with interior walls fused with a $40 \mu \mathrm{m}$ PTFE Teflon coating. Details of chamber operation, sample collection, derivatization procedure, and the GC-MS analysis method are described in more detail in Lewandowski et al. (2015) and Jaoui et al. (2004). A combination of UVfluorescent bulbs was used in the chamber as a source of radiation from 300 to $400 \mathrm{~nm}$ with a distribution photolytically comparable to that of solar radiation (Black et al., 1998). The reaction chamber was operated as a flow reactor with a residence time of $4 \mathrm{~h}$, to produce a steady-state, constant aerosol distribution which could be repeatedly sampled at different seed aerosol acidities.

Isoprene and nitric oxide (NO) were taken from highpressure cylinders each diluted with $\mathrm{N}_{2}$. Isoprene was obtained from Sigma-Aldrich Chemical Co. (Milwaukee, WI, USA) at the highest purity available and used without further purification. Isoprene and NO were added to the chamber through flow controllers. The temperature in all experiments was $\sim 27^{\circ} \mathrm{C}$ (Table 1). Dilute aqueous solutions of ammonium sulfate and sulfuric acid as inorganic seed aerosol were nebulized to the chamber, with total sulfate concentration of the combined solution held constant to maintain stable inorganic concentrations in the chamber (Lewandowski et al., 2015). NO and total oxides of nitrogen $\left(\mathrm{NO}_{x}\right)$ were measured with a Thermo Electron $\mathrm{NO}_{x}$ analyzer (Model 8840, Thermo Environmental, Inc., Franklin, MA, USA). Ozone formed during the irradiation was measured with a Bendix ozone monitor (Model 8002, Lewisburg, WV, USA). Temperature and relative humidity were measured with an Omega Digital Thermo-Hygrometer (Model RH411, Omega Engineering, Inc., Stamford, CT, USA). Isoprene concentrations were measured by gas chromatography with flame ionization detection (Hewlett-Packard, Model 5890 GC). Chamber filter samples were collected for $24 \mathrm{~h}$ at $16.7 \mathrm{~L} \mathrm{~min}^{-1}$ using $47 \mathrm{~mm}$ glass fiber filters (Pall Gelman Laboratory, Ann Arbor, MI, USA).

Two sets of experiments were conducted (Table 1) to explore the effect of humidity and acidity on isoprene SOA products. The non-acidic experiment (ER667) was conducted at four different humidity levels in the presence of isoprene, $\mathrm{NO}_{x}$, and ammonium sulfate as seed aerosol $\left(1 \mu \mathrm{g} \mathrm{m}^{-3}\right)$. It served as a base case for exploring the changes and nature of SOA products in the absence of significant aerosol acidity. The second experiment (ER662, acidic) was similar but run in the presence of acidic seed aerosol at constant concentration. It included five and four stages differing in humidity levels for ER667 (9\%, 19\%, 30\%, 39\%, and $49 \%)$ and ER662 (8\%, $18 \%, 28 \%$, and $44 \%)$, respectively. Aerosol concentrations are those from Lewandowski et al. (2015).

\subsection{Ambient aerosol samples}

Twenty ambient $\mathrm{PM}_{2.5}$ samples were collected, onto prebaked quartz filters using a high-volume aerosol sampler (DHA-80, Digitel), from two sites (10 samples each) that have strong isoprene emissions: (1) a regional background monitoring station in Zielonka, in the Kuyavian-Pomeranian Province in northern Poland (PL; 53 $39^{\prime} \mathrm{N}, 17^{\circ} 55^{\prime} \mathrm{E}$ ), during the summer 2016 campaign and (2) a regional background monitoring station in Godów, PL, located in the Silesian Province $\left(49^{\circ} 55^{\prime} \mathrm{N}, 18^{\circ} 28^{\prime} \mathrm{E}\right)$ in the summer $2014 \mathrm{cam}$ paign. Sampling times were 12 and $24 \mathrm{~h}$, respectively. Major tree species at both sites are European oak (Quercus robur, L.), European hornbeam (Carpinus betulus, L.), Tilia cordata (Tilia cordata Mill), European white birch (Betula pubescens Ehrh), and European alder (Alnus glutinosa Gaertn). The Zielonka station is in a forested area, while the Godów station is located near a coal-fired power station in Dětmarovice (Czech Republic). Godów is also close to the major industrial cities of the Silesian region in Poland, and thus aerosol samples collected in Godów were influenced by anthropogenic sources.

Several chemical and physical parameters were measured at the two sites. The temperature during sampling at both 
sites ranged from 25 to $28^{\circ} \mathrm{C}$. The relative humidity during sampling was up to $86 \%$ in Zielonka and $94 \%$ at Godów. Both locations were influenced by $\mathrm{NO}_{x}$ concentration, modestly in Zielonka at $1.3 \mu \mathrm{g} \mathrm{m}^{-3}$ and at a level of $30 \mu \mathrm{g} \mathrm{m}^{-3}$ in Godów, represented by the nearest monitoring station at Żywiec, PL. The $\mathrm{SO}_{2}$ levels at Zielonka were approximately 0.6 and $3.0 \mu \mathrm{g} \mathrm{m}^{-3}$ at Godów. At each site, organic carbon / elemental carbon ratio (OC/EC) values was determined for each filter using a thermo-optical method (Birch and Cary, 1996). The organic carbon value at Zielonka was approximately 1.7 and $5.4 \mu \mathrm{g} \mathrm{m}^{-3}$ at Godów, although aerosol masses were not determined.

\subsection{Instrumentation and analysis methods}

Chemicals for extraction and derivatization were obtained from Sigma-Aldrich Chemical Company. N,Obis(trimethylsilyl)trifluoroacetamide (BSTFA) used as the derivatizing agent included $1 \%$ trimethylchlorosilane as a catalyst. For the GC-MS analysis, filters were sonicated for $1 \mathrm{~h}$ with methanol. Prior to extraction, $20 \mu \mathrm{g}$ each of cisketopinic acid and $d_{50}$-tetracosane was added as internal standards. Following sonication, the methanol extracts were dried and then derivatized with $200 \mu \mathrm{L}$ BSTFA and $100 \mu \mathrm{L}$ pyridine. Samples were then heated to $70^{\circ} \mathrm{C}$ to complete the reaction (Jaoui et al., 2004). The derivatized extracts were analyzed using a ThermoQuest (Austin, TX, USA) GC coupled to an ion trap mass spectrometer (ITMS). The injector, heated to $270^{\circ} \mathrm{C}$, was operated in splitless mode. Compounds were separated on a $60 \mathrm{~m}$ long, $0.25 \mathrm{~mm}$ ID RTx-5MS column (Restek, Inc., Bellefonte, PA, USA) with a $0.25 \mu \mathrm{m}$ film thickness. The GC oven temperature program for the analysis started isothermally at $84^{\circ} \mathrm{C}$ for $1 \mathrm{~min}$, followed by a temperature ramp of $8{ }^{\circ} \mathrm{C} \mathrm{min}^{-1}$ to $200^{\circ} \mathrm{C}$ and a $2 \mathrm{~min}$ hold, and was then ramped at $10^{\circ} \mathrm{C} \mathrm{min}^{-1}$ to $300^{\circ} \mathrm{C}$. The ion source, ion trap, and interface temperatures were 200 , 200 , and $300^{\circ} \mathrm{C}$, respectively. Mass spectra were collected in both the chemical ionization (CI) and electron ionization (EI) modes (Jaoui et al., 2004). A semi-continuous OC/EC analyzer (Sunset Laboratories, Tigard, OR, USA) measured total organic carbon of the aerosol given the absence of elemental carbon in the reaction system. Immediately upstream of the analyzer, a carbon-strip denuder was placed in line to remove gas-phase organic components which could bias the measurements. The analyses for total OC were made on a 15 min duty cycle. Silylation of polar compounds results in reduced polarity, enhanced volatility, and increased thermal stability, and they enable the GC-MS analysis of many compounds otherwise involatile or too unstable for these techniques. Therefore, appropriate caution should be taken, for example, with desulfation reactions associated with primary organosulfates (Takano et al., 1992; Kolender et al., 2004; Bedini et al., 2016, 2017; Cui et al., 2018), and corrections might be warranted when analyzing methyltetrols.
For the LC-MS analysis, from each filter, two $1 \mathrm{~cm}^{2}$ punches were taken and twice extracted for $30 \mathrm{~min}$ with $15 \mathrm{~mL}$ aliquots of methanol using a Multi-Orbital Shaker (PSU-20i, BioSan). High-purity methanol (LC-MS Chromasolv grade; Sigma-Aldrich, PL) was used for the extraction of SOA filters, reconstitution of aerosol extracts, and preparation of the LC mobile phase. The two extracts were combined and concentrated to $1 \mathrm{~mL}$ using a rotary evaporator operated at $28^{\circ} \mathrm{C}$ and 150 mbar (Rotavapor ${ }^{\circledR} \mathrm{R} 215$, Buchi). They were then filtered with a $0.2 \mu \mathrm{m}$ PTFE syringe and taken to dryness under a gentle stream of nitrogen. High-purity water (resistivity $18.2 \mathrm{M} \Omega \times \mathrm{cm}^{-1}$ ) from a Milli-Q Advantage water purification system (Merck, Poland) was used for the reconstitution of aerosol extracts and preparation of the LC mobile phase. The residues were reconstituted with $180 \mu \mathrm{L}$ of $1: 1$ high-purity methanol/water mixture $(v / v)$ and then agitated for $1 \mathrm{~min}$. Recoveries were not taken for compounds analyzed in this study, due to lack of authentic standards; however, recovery of $94 \%-101 \%$ was measured for appropriate surrogate compounds.

Extracts were analyzed by ultra-high performance liquid chromatography-electrospray ionization (ESI)-quadruple time-of-flight high-resolution mass spectrometry equipment consisting of a Waters ACQUITY UPLC I-Class chromatograph coupled to a Waters SYNAPT G2-S highresolution mass spectrometer. The chromatographic separations were performed using an ACQUITY HSS T3 column $(2.1 \times 100 \mathrm{~mm}, 1.8 \mu \mathrm{m}$ particle size $)$ at room temperature. The mobile phases consisted of $10 \mathrm{mM}$ ammonium acetate (eluent A) and methanol (eluent B). To obtain appropriate chromatographic separations and responses, a gradient elution program 13 min in length was used. The chromatographic run commenced with $100 \%$ eluent A over the first 3 min. Eluent B increased from $0 \%$ to $100 \%$ from 3 to $8 \mathrm{~min}$, held constant at $100 \%$ from 8 to $10 \mathrm{~min}$, and then decreased back from $100 \%$ to $0 \%$ from 10 to $13 \mathrm{~min}$. The initial and final flow was $0.35 \mathrm{~mL} \mathrm{~min}^{-1}$, while the flow from 3 to $10 \mathrm{~min}$ was $0.25 \mathrm{~mL} \mathrm{~min}^{-1}$. An injection volume of $0.5 \mu \mathrm{L}$ was used. The SYNAPT G2-S spectrometer equipped with an ESI source was operated in the negative-ion mode. Optimal ESI source conditions were $3 \mathrm{kV}$ capillary voltage with a $20 \mathrm{~V}$ sampling cone and full-width-at-half-maximum mass-resolving power of 20000 . High-resolution mass spectra were recorded from $m / z 50$ to 600 in the MS or MS/MS modes. All data were recorded and analyzed with the Waters MassLynx V4.1 software package. During the analyses, the mass spectrometer was continuously calibrated by injecting the reference compound, leucine enkephalin, directly into the ESI source. 

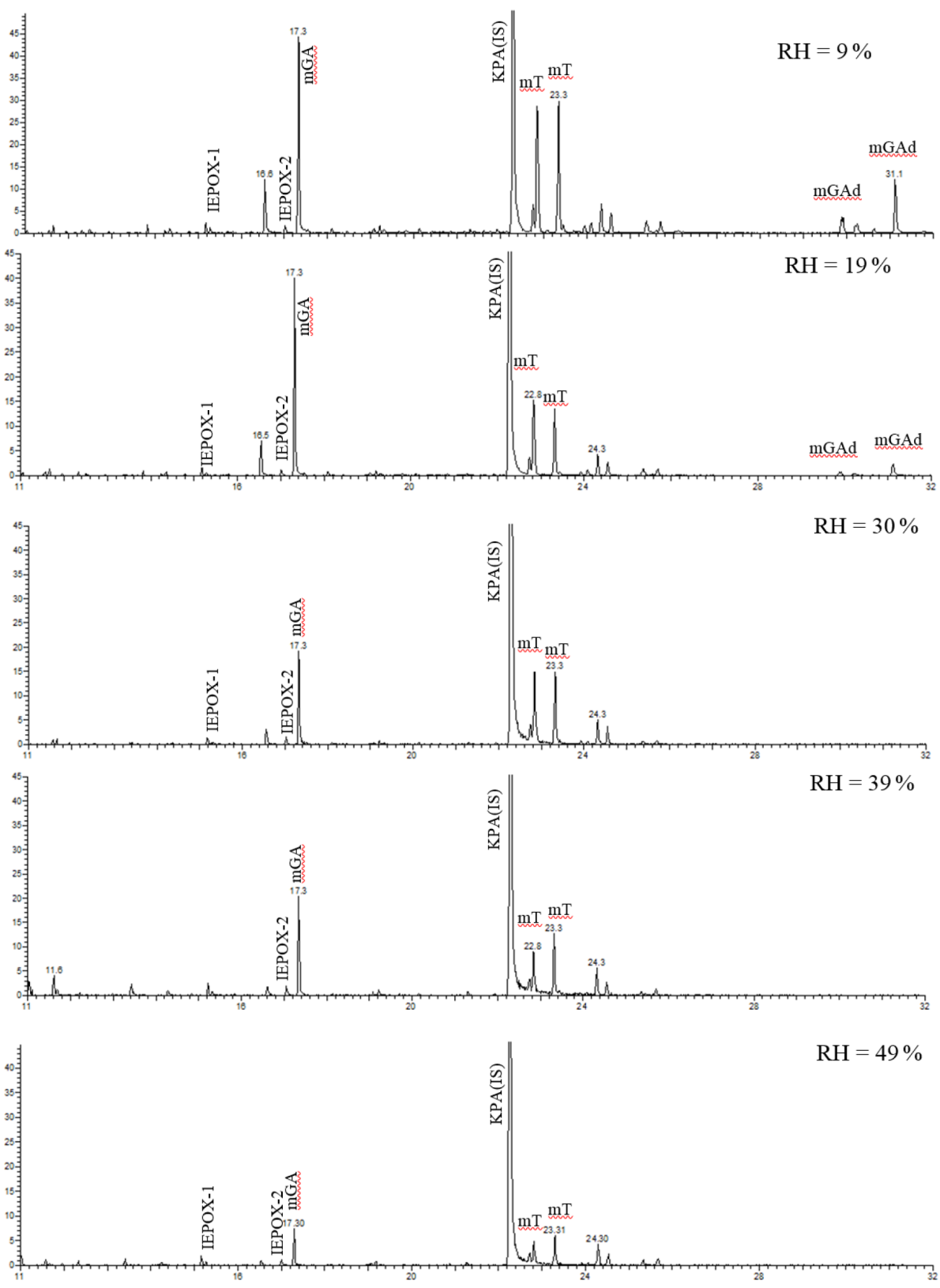

Figure 1. Extracted-ion chromatograms (KPA: $m / z$ 165, ketopinic acid, IS (internal standards); IEPOX: $m / z$ 173, two isomers; $2 \mathrm{mGA}$ : 321; 2-methylglyceric acid; 2MT: $m / z$ 409, 2-methyltetrols, four isomers; mGAd: $m / z$ 495, 2-methylglyceric acid dimer, three isomers) for non-acidic isoprene/ $\mathrm{NO}_{x}$ photooxidation experiments as a function of RH. Compounds were detected as silylated derivatives. For clarity of the figure, not all isomers are shown.

\section{Results and discussion}

\subsection{Chemical characterization}

Table 1 shows the input and steady-state conditions for all stages of the chamber experiments, including the values determined for carbon yield, secondary organic carbon, and organic-mass-to-carbon-mass ratio (OM/OC). The data indicate that with increasing RH the formation of SOC and carbon yield is reduced, under both acidic and non-acidic condi- tions. The results obtained are consistent with those of Zhang et al. (2011). Secondary organic aerosol formed under nonacidic conditions was additionally analyzed for $\mathrm{OM} / \mathrm{OC}$ and SOA yield. The average OM/OC ratio was $1.92 \pm 0.13$, and the average laboratory SOA yield measured in this experiment was $0.0032 \pm 0.0004$. For the non-acidic experiment, the carbon yield values range from a low 0.001 (stage 5, Table 1) at the highest relative humidity to a high of 0.004 at the lowest relative humidity (stage 1 , Table 1 ). For the acidified 
experiment, carbon yield declined from above 0.011 at the lowest relative humidity $(8 \%)$ to 0.0013 at the highest relative humidity (44\%). Although the relative humidity considered for both acidic and non-acidic experiments do not correspond precisely, an increase of SOC was observed under acidic conditions at approximately the same relative humidity. The values of SOA yields agree with previous chamber studies reported in the literature under the same nominal conditions in the presence of $\mathrm{NO}_{x}$ (Edney et al., 2005; Dommen et al., 2006; Surratt et al., 2007; Zhang et al., 2011).

The analysis of isoprene SOA from chamber experiments and field samples is based on the interpretation of mass spectra of the derivatized and underivatized isoprene SOA products by GC-MS (in EI and CI) and by LC-MS (negative-ion mode with electrospray ionization), respectively. The characteristic ions for all BSTFA derivatives are $m / z 73,75,147$, and 149. In CI mode, adduct ions from the derivatives included $m / z \mathbf{M}^{+\bullet}+73, \mathbf{M}^{+\bullet}+41, \mathbf{M}^{+\bullet}+29$, and $\mathbf{M}^{+\bullet}+1$, while fragment ions included $m / z \mathbf{M}^{+\bullet}-15$, $\mathrm{M}^{+\bullet}-73, \mathrm{M}^{+\bullet}-89, \mathrm{M}^{+\bullet}-117, \mathrm{M}^{+} \bullet-105, \mathrm{M}^{+} \bullet-133$, and $\mathrm{M}^{+\bullet}-207$ (Jaoui et al., 2004). The LC-MS analysis used to identify organosulfates and nitroxy- and nitrosoxyorganosulfates is based on the deprotonated ions $[\mathrm{M}-\mathrm{H}]^{-}$ and the corresponding fragmentation pathways. Organosulfates were recognized by the loss of characteristic ions of $\mathrm{m} / z \quad 80\left(\mathrm{SO}_{3}^{-}\right), 96\left(\mathrm{SO}_{4}^{-}\right)$, and $97\left(\mathrm{HSO}_{4}^{-}\right)$(Darer et al., 2011; Szmigielski 2016). The nitroxy-organosulfates and nitrosoxy-organosulfates were identified from additional neutral losses of $m / z 63\left(\mathrm{HNO}_{3}\right)$ and $m / z 47\left(\mathrm{HNO}_{3}\right)$, respectively. Table 2 presents the list of compounds tentatively identified in the present study along with proposed structures, MWs, and main fragmentation ions $(\mathrm{m} / \mathrm{z})$. Additional organic acids were tentatively identified in this study, and further work is being conducted to understand their role in isoprene SOA. At the present time, the organosulfate (MW 230), 2-methyltartaric acid organosulfate (MW 244), and 2-methyltartaric acid nitroxy-organosulfate (MW 275) appear not to have been reported before. An organosulfate with MW 230, but with a distinct structure, was recently reported in the literature from the photooxidation of 2-Epentanal (Shalamzari et al., 2016).

Figure 1 presents GC-MS extracted-ion chromatograms (EICs) from the aerosol obtained during the non-acidic experiment (isoprene non-acidic-seed irradiation) at a wide range of relative humidities. According to acquired chromatograms shown in Fig. 1, several isomers associated with the compounds analyzed can be distinguished, i.e., IEPOX-1 and IEPOX-2, four isomers of 2-methyltetrols, and their relative contributions to SOA masses at various relative humidity levels.

The formation of isoprene SOA products such as 2methyltetrols (mT) and 2-methylglyceric acid is well documented in the literature. These compounds are isoprene SOA markers and have been reported in numerous field and chamber studies under low- and high- $\mathrm{NO}_{x}$ conditions (Claeys et

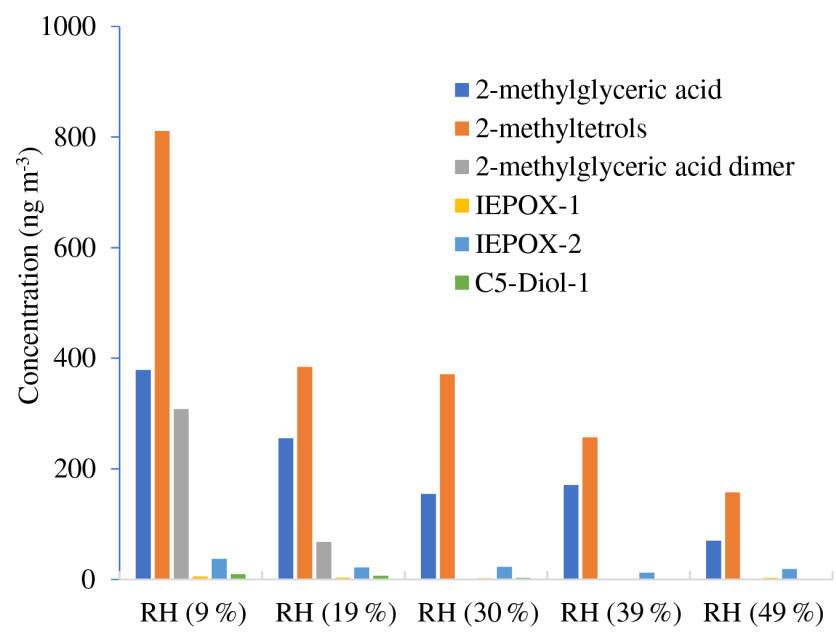

Figure 2. Concentrations of particle-phase products from the nonacidic-seed experiments (non-acidic) estimated with GC-MS.

al., 2004a; Edney et al., 2005; Kroll et al., 2006; Surratt et al., $2006,2010)$. The formation mechanism under low- $\mathrm{NO}_{x}$ conditions has been explained by the reactive uptake of IEPOX onto acidic aerosol seeds (Paulot et al., 2009; Surratt et al., 2010) and under high- $\mathrm{NO}_{x}$ conditions by the further oxidation of methacryloyl peroxynitrate (MPAN) (Chan et al., 2010; Surratt et al., 2010; Nguyen et al., 2015).

The LC-MS analyses focused mainly on the formation of the variety of organosulfates and nitroxy- and nitrosoxyorganosulfates. Mass spectra and proposed fragmentation pathways of newly identified components are presented in Sect. 3.4.

\subsection{Effect of relative humidity and acidity on product formation}

\subsubsection{Non-acidic aerosol}

Table 3 and Figs. 2-3 present the estimated amounts of polar oxygenated products detected with GC-MS and LC-MS techniques in samples from non-acidic photooxidation experiments with non-acidic aerosol seeds under various RH conditions. Six products were quantified (as sums of respective isomers) based on the response factor of ketopinic acid using GC-MS. Nine other compounds were detected qualitatively using LC-MS, with chromatographic responses representing the amounts of respective analytes. Therefore, the results should be understood as a tendency of product occurrence in the chamber experiments rather than the real amounts formed. Table 3 does not contain data on 2-methyltartaric acid organosulfate (MW 244) because it occurred in the samples merely in trace amounts.

The major SOA components detected were 2methyltetrols, 2-methylglyceric acid, and its dimer, whose maximal estimated concentrations exceeded 800,350 , and $300 \mathrm{ng} \mathrm{m}^{-3}$, respectively, under low-humidity conditions of 
Table 1. Initial and steady-state conditions, yields, and OM/OC data for chamber experiments on isoprene photooxidation in the presence of acidic and non-acidic seed aerosol. The initial $\mathrm{NO}_{x}$ was entirely nitric oxide. The non-acidic experiment was conducted with a lowconcentration ammonium sulfate seed $\left(\sim 1 \mu \mathrm{g} \mathrm{m}^{-3}\right)$. The acidic experiment was conducted with a higher concentration of inorganic seed $\left(\sim 30 \mathrm{\mu} \mathrm{m}^{-3}\right)$ generated from a nebulized solution for which half the sulfate mass was derived from sulfuric acid and the other half from ammonium sulfate (Lewandowski et al., 2015).

\begin{tabular}{|c|c|c|c|c|c|}
\hline \multicolumn{6}{|c|}{$\begin{array}{l}\text { Experiment ER662: acidic seed aerosol ( } 1 / 2 \text { ammonium sulfate, } \\
1 / 2 \text { sulfuric acid by sulfate mass in precursor solution) }\end{array}$} \\
\hline & Stage 1 & Stage 2 & Stage 3 & \multicolumn{2}{|c|}{ Stage 4} \\
\hline $\mathrm{RH}(\%)$ & 8 & 28 & 44 & \multicolumn{2}{|c|}{18} \\
\hline Temperature (C) & 27.0 & 27.3 & 26.9 & \multicolumn{2}{|c|}{27.5} \\
\hline Initial isoprene (ppmC & 6.82 & 6.92 & 7.01 & \multicolumn{2}{|c|}{7.03} \\
\hline Initial NO (ppm) & 0.296 & 0.296 & 0.296 & \multicolumn{2}{|c|}{0.296} \\
\hline \multicolumn{6}{|l|}{ Steady-state conditions } \\
\hline $\mathrm{O}_{3}(\mathrm{ppm})$ & 0.303 & 0.292 & 0.245 & \multicolumn{2}{|c|}{0.339} \\
\hline $\mathrm{NO}_{x}(\mathrm{ppm})$ & 0.220 & 0.213 & 0.205 & \multicolumn{2}{|c|}{0.234} \\
\hline$\Delta \mathrm{HC}\left(\mu \mathrm{g} \mathrm{m}^{-3}\right)$ & 3266 & 3318 & 3357 & 34 & 72 \\
\hline Carbon yield & 0.011 & 0.002 & 0.001 & 0.00 & \\
\hline $\operatorname{SOC}\left(\mu \mathrm{gC} \mathrm{m}^{-3}\right)$ & 32 & & 9 & 15 & .7 \\
\hline Experiment ER667 & Non-acidi & c seed aer & ssol (ammo & nium sulf & te) \\
\hline & Stage 1 & Stage 2 & Stage 3 & Stage 4 & Stage 5 \\
\hline $\mathrm{RH}(\%)$ & 9 & 19 & 30 & 39 & 49 \\
\hline Temperature (C) & 28.2 & 28.5 & 27.9 & 27.8 & 27.6 \\
\hline Initial isoprene (ppmC) & 8.11 & 8.29 & 8.25 & 8.25 & 8.19 \\
\hline Initial NO (ppm) & 0.347 & 0.347 & 0.347 & 0.347 & 0.347 \\
\hline Steady-state conditions & & & & & \\
\hline $\mathrm{O}_{3}(\mathrm{ppm})$ & 0.331 & 0.305 & 0.329 & 0.393 & 0.281 \\
\hline $\mathrm{NO}_{x}(\mathrm{ppm})$ & 0.260 & 0.247 & 0.241 & 0.229 & 0.226 \\
\hline$\Delta \mathrm{HC}\left(\mu \mathrm{g} \mathrm{m}^{-3}\right)$ & 3518 & 3556 & 3558 & 3515 & 3484 \\
\hline SOA yield & 0.007 & 0.004 & 0.002 & 0.002 & 0.001 \\
\hline Carbon yield & 0.0038 & 0.0022 & 0.0013 & 0.0009 & 0.0010 \\
\hline $\mathrm{SOC}\left(\mu \mathrm{gC} \mathrm{m}{ }^{-3}\right)$ & 13.3 & 7.7 & 4.6 & 3.2 & 3.5 \\
\hline $\mathrm{OM} / \mathrm{OC}$ & 1.96 & 2.00 & 2.02 & 2.03 & 1.59 \\
\hline
\end{tabular}

RH $9 \%$ (Fig. 2). At the two lowest humidities, aerosol liquid water is expected to be very low, and the decrease in these compounds may not be controlled by aerosol liquid water but possibly by the SOC levels associated with the particles (Lewandowski et al., 2015), although chamber-related wall effects due to water vapor might also play some role. Among compounds detected with LC-MS (Fig. 3) are organosulfates derived from acid-catalyzed multiphase chemistry of IEPOX (MW 216) and MAE/HMML (methacrylic acid epoxide/hydroxymethyl-methyl- $\alpha$-lactone) (MW 200) (Surratt et al., 2010; Lin et al., 2012, 2013; Nguyen et al., 2015). Other components were significantly less abundant. In most cases, increasing the humidity resulted in decreased yields of the products detected, although some compounds were observed at higher concentrations at $\mathrm{RH} 49 \%$ compared to RH $9 \%$ (i.e., $m / z$ 199: Fig. 3). As found in Table 1, total SOC decreased with increased humidity. Generally, the influence of $\mathrm{RH}$ on the product yields was modest, consistent with Dommen et al. (2006) and Nguyen et al. (2011), who saw a negligible effect of relative humidity on SOA yield in photooxidation of isoprene in the absence of acidic seed aerosol. By contrast, here the 2-methyltetrols, 2-methylglyceric acid, and 2-methylglyceric acid dimer were found in significantly larger quantities at RH 9\% compared to RH 49\%. Two recent studies (Lin et al., 2014; Riva et al., 2016) reported an increase in aerosol mass with increasing RH. Riva et al. (2016) also reported an increase in 2-methyltetrols concentrations with increasing $\mathrm{RH}$. However, the initial conditions for those two studies differed substantially from those in the present study. Here, isoprene is oxidized in the presence of $\mathrm{NO}_{x}$ and seed aerosol (acidic and non-acidic) under a wide range of RH. In contrast, in 
Table 2. Products detected in SOA samples from chamber experiments using GC-MS and LC-MS.

\begin{tabular}{|c|c|c|c|c|}
\hline $\begin{array}{l}\text { Chemical } \\
\text { formula }\end{array}$ & $\begin{array}{l}m / z \text { BSTFA derivative } \\
\text { (methane-CI) }\end{array}$ & $\begin{array}{l}\text { MW MW } \\
\left(\mathrm{g} \mathrm{mol}^{-1}\right)\end{array}$ & $\begin{array}{l}\text { Tentative structure* } \\
\text { and chemical name }\end{array}$ & References \\
\hline \multicolumn{5}{|l|}{ GC-MS } \\
\hline $\mathrm{C}_{5} \mathrm{H}_{10} \mathrm{O}_{2}$ & $247,231,157,147,73$ & $\begin{array}{l}102 \\
246\end{array}$ & $\begin{array}{l}\mathrm{OH} \\
\text { 3-methyl-3-butene-1,2-diol } \\
\left(\mathrm{C}_{5} \text {-diol-1) }\right.\end{array}$ & $\begin{array}{l}\text { Wang et al. (2005) } \\
\text { Surratt et al. (2006) }\end{array}$ \\
\hline $\mathrm{C}_{5} \mathrm{H}_{10} \mathrm{O}_{2}$ & $263,247,173,83,73$ & $\begin{array}{l}118 \\
262\end{array}$ & $\begin{array}{l}\mathrm{OH} \\
\text { 2-methyl-2,3-epoxy-but-1,4-diol } \\
\text { (IEPOX-1) }\end{array}$ & $\begin{array}{l}\text { Paulot et al. (2009) } \\
\text { Surratt et al. (2010) } \\
\text { Zhang et al. (2012) }\end{array}$ \\
\hline $\mathrm{C}_{5} \mathrm{H}_{18} \mathrm{O}_{3}$ & $263,247,173,83,73$ & $\begin{array}{l}118 \\
262\end{array}$ & $\begin{array}{l}\text { O } \\
\text { 2-methyl-3,4-epoxy-but-1,2-diol } \\
\text { (IEPOX-2) }\end{array}$ & \\
\hline $\mathrm{C}_{4} \mathrm{H}_{8} \mathrm{O}_{4}$ & $337,321,293,219,203$ & $\begin{array}{l}120 \\
336\end{array}$ & $\frac{\mathrm{OH}}{\text { 2-methylglyceric acid (2-MG) }}$ & $\begin{array}{l}\text { Claeys et al. (2004a) } \\
\text { Surratt et al. (2006) } \\
\text { Edney et al. (2005) } \\
\text { Szmigielski et al. (2007) }\end{array}$ \\
\hline $\mathrm{C}_{5} \mathrm{H}_{12} \mathrm{O}_{4}$ & $409,319,293,219,203$ & $\begin{array}{l}136 \\
424\end{array}$ & $\begin{array}{c}\mathrm{OH} \\
\text { 2-methylthreitol (2MT) }\end{array}$ & $\begin{array}{l}\text { Claeys et al. (2004a) } \\
\text { Wang et al. (2004) } \\
\text { Edney et al. (2005) } \\
\text { Surratt et al. (2006) } \\
\text { Nozière et al. (2011) }\end{array}$ \\
\hline $\mathrm{C}_{5} \mathrm{H}_{12} \mathrm{O}_{4}$ & $409,319,293,219,203$ & $\begin{array}{l}136 \\
424\end{array}$ & $\frac{\mathrm{OH}}{\text { 2-methylerythritol (2MT) }}$ & \\
\hline $\mathrm{C}_{8} \mathrm{H}_{14} \mathrm{O}_{7}$ & $495,321,219,203,73$ & $\begin{array}{l}222 \\
510\end{array}$ & $\begin{array}{l}\text { 2-methylglyceric acid dimer } \\
\text { (2-MG dimer) }\end{array}$ & $\begin{array}{l}\text { Surratt et al. (2006) } \\
\text { Szmigielski et al. (2007) }\end{array}$ \\
\hline
\end{tabular}


Table 2. Continued.

\begin{tabular}{|c|c|c|c|c|}
\hline $\begin{array}{l}\text { Chemical } \\
\text { formula }\end{array}$ & $\begin{array}{l}m / z \text { BSTFA derivative } \\
\text { (methane-CI) }\end{array}$ & $\begin{array}{l}\text { MW MW } \\
\left(\mathrm{g} \mathrm{mol}^{-1}\right)\end{array}$ & $\begin{array}{l}\text { Tentative structure* } \\
\text { and chemical name }\end{array}$ & References \\
\hline \multicolumn{5}{|l|}{ LC-MS } \\
\hline $\mathrm{C}_{5} \mathrm{H}_{10} \mathrm{O}_{6} \mathrm{~S}$ & $197,167,97,81$ & 198 & IEPOX-derived organosulfate & Tao et al. (2014) \\
\hline $\mathrm{C}_{4} \mathrm{H}_{8} \mathrm{O}_{7} \mathrm{~S}$ & $199,119,97,73$ & 200 & $\begin{array}{l}\quad \mathrm{O} \\
\text { 2-methylglyceric acid } \\
\text { organosulfate } \\
\text { (2-MG OS) }\end{array}$ & $\begin{array}{l}\text { Surratt et al. (2007a) } \\
\text { Gomez-Gonzalez et al. (2008) } \\
\text { Shalamzari et al. (2013) } \\
\text { Riva et al. (2016) }\end{array}$ \\
\hline $\mathrm{C}_{5} \mathrm{H}_{8} \mathrm{O}_{7} \mathrm{~S}$ & $211,193,113,97$ & 212 & $\begin{array}{l}2(3 \mathrm{H}) \text {-furanone, } \\
\text { dihydro-3,4-dihydroxy-3-methyl } \\
\text { organosulfate }\end{array}$ & $\begin{array}{l}\text { Surratt et al. (2008) } \\
\text { Hettiyadura et al. (2015) } \\
\text { Spolnik et al. (2018) }\end{array}$ \\
\hline $\mathrm{C}_{5} \mathrm{H}_{10} \mathrm{O}_{7} \mathrm{~S}$ & $213,183,153,97$ & 214 & $\begin{array}{l}\text { 2,3,4-furantriol, } \\
\text { tetrahydro-3-methyl-organosulfate }\end{array}$ & $\begin{array}{l}\text { Hettiyadura et al. (2015) } \\
\text { Spolnik et al. (2018) }\end{array}$ \\
\hline $\mathrm{C}_{5} \mathrm{H}_{12} \mathrm{O}_{7} \mathrm{~S}$ & 215,97 & 216 & $\begin{array}{l}\mathrm{OH} \mathrm{OH} \\
\text { 2-methyltetrol organosulfate } \\
\text { (2MT OS) }\end{array}$ & $\begin{array}{l}\text { Surratt et al. (2007a) } \\
\text { Gomez-Gonzalez et al. (2008) } \\
\text { Surratt et al. (2010) }\end{array}$ \\
\hline $\mathrm{C}_{5} \mathrm{H}_{10} \mathrm{O}_{8} \mathrm{~S}$ & $229,149,97,75$ & 230 & $\begin{array}{l}\mathrm{HO}_{3} \mathrm{SO} \quad \mathrm{OH} \\
\text { 2-methylthreonic acid } \\
\text { organosulfate }\end{array}$ & This study \\
\hline $\mathrm{C}_{5} \mathrm{H}_{9} \mathrm{O}_{9} \mathrm{~S}$ & $243,163,145,101$ & 244 & $\begin{array}{c}\mathrm{O} \quad \mathrm{OSO}_{3} \mathrm{H} \\
\text { 2-methyltartaric acid organosulfate }\end{array}$ & This study \\
\hline
\end{tabular}


Table 2. Continued.

\begin{tabular}{|c|c|c|c|c|}
\hline $\begin{array}{l}\text { Chemical } \\
\text { formula }\end{array}$ & $\begin{array}{l}m / z \text { BSTFA derivative } \\
\text { (methane-CI) }\end{array}$ & $\begin{array}{l}\text { MW MW BSTFA } \\
\left(\mathrm{g} \mathrm{mol}^{-1}\right)\end{array}$ & $\begin{array}{l}\text { Tentative structure* } \\
\text { and chemical name }\end{array}$ & References \\
\hline LC-MS & & & & \\
\hline $\mathrm{C}_{5} \mathrm{H}_{11} \mathrm{NO}_{8} \mathrm{~S}$ & $244,226,197,183,153,97$ & 245 & $\begin{array}{c}\mathrm{OH} \\
\text { 2-methyltetrol nitrosoxy-organosulfate }\end{array}$ & This study \\
\hline $\mathrm{C}_{5} \mathrm{H}_{11} \mathrm{NO}_{9} \mathrm{~S}$ & $260,197,183,153,97$ & 261 & $\begin{array}{l}\mathrm{OH} \quad \mathrm{OSO}_{3} \mathrm{H} \\
\text { 2-methyltetrol nitroxy-organosulfate }\end{array}$ & $\begin{array}{l}\text { Surratt et al. (2007a) } \\
\text { Surratt et al. (2008) }\end{array}$ \\
\hline $\mathrm{C}_{5} \mathrm{H}_{9} \mathrm{NO}_{10} \mathrm{~S}$ & $274,211,193,153,97$ & 275 & $\begin{array}{l}\mathrm{O} \quad \mathrm{OSO}_{3} \mathrm{H} \\
\text { 2-methylthreonic acid } \\
\text { nitroxy-organosulfate }\end{array}$ & This study \\
\hline
\end{tabular}

* For more stereochemically complex molecules a representative isomer is shown.

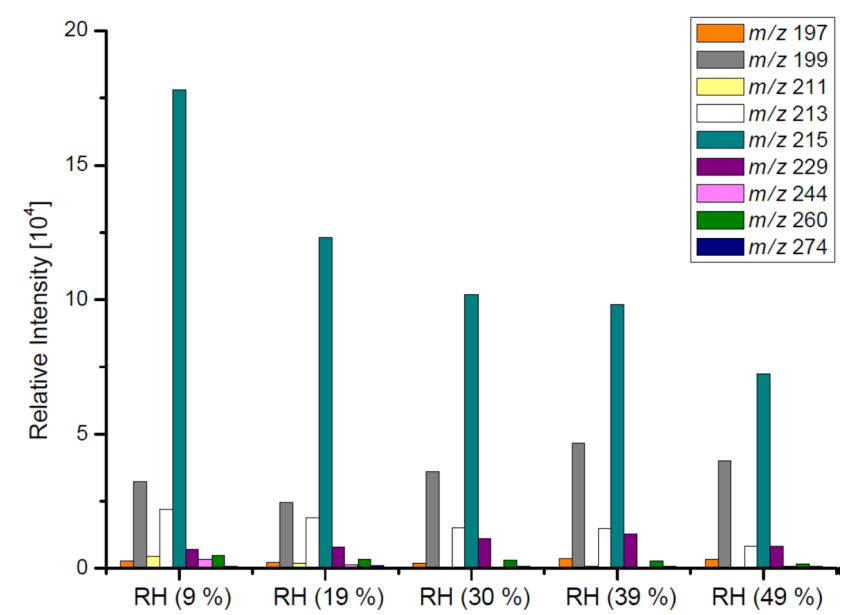

Figure 3. LC-MS chromatographic responses of OS and NOSs from the non-acidic-seed experiments (non-acidic).

Riva et al. (2016) and Lin et al., 2012, the reactants were hydroxyhydroperoxide (ISOPOOH) and IEPOX oxidized under $\mathrm{NO}_{x}$-free conditions at two levels of RH. In addition, organosulfates, 2-methyltetrols, and SOA yields derived from isoprene photooxidation typically have been enhanced under acidic conditions (Surratt et al., 2007a, b, 2010; Gomez-Gonzalez et al., 2008; Jaoui et al., 2010; Zhang et al., 2011). Organosulfates have also been formed in non-acidic experiments, probably through radical-initiated reactions in wet aerosol particles containing sulfate moieties
(Noziere et al., 2010; Perri et al., 2010). The NOS and OS compounds detected here could have been formed via such a mechanism.

\subsubsection{Acidic seed aerosol}

Table 4 and Figs. 4-5 present the estimated amounts of polar oxygenated products detected using GC-MS and LC-MS techniques in samples from the acidic photooxidation experiments with acidic aerosol seed under various RH conditions. We detected the same compounds as in the nonacidic-seed experiments, with the same analytical limitations of the quantitation. The presence of 2-methyltetrols and 2methylglyceric acid and their sulfated analogues in isoprene SOA at a wide range of RH conditions suggests that SOA water content does not significantly affect their formation.

Early chamber studies on isoprene ozonolysis by Jang et al. (2002) and Czoschke et al. (2003) showed enhanced SOA yields in the presence of acidified aerosol seeds. Recent laboratory results showed that the acidity of aerosol seeds plays a major role in the reactive uptake of isoprene oxidation products by particle phases (Paulot et al., 2009; Surratt et al., 2010; Lin et al., 2012; Gaston et al., 2014a, b; Riedel et al., 2015). In our study, SOC produced in acidic-seed experiments was always higher than in non-acidic-seed ones under the corresponding RH conditions, while the difference diminished with increasing $\mathrm{RH}$ to a negligible value of $0.3 \mu \mathrm{g} \mathrm{C} \mathrm{m}^{-3}$ at $\mathrm{RH} 44 \%-49 \%$ (Table 1 and Fig. S1 in the Supplement; Surratt et al., 2007a). However, the formation of the individual organic compounds did not follow the 
Table 3. Estimated concentrations of reaction products $\left(\mathrm{ng} \mathrm{m}^{-3}\right)$ from the non-acidic photooxidation experiments (neutral seed $\left[\mathrm{H}^{+}\right]=54 \mathrm{nmol} \mathrm{m}^{-3}$ air; Lewandowski et al., 2015).

\begin{tabular}{lrrrrr}
\hline & RH 9 $(\%)$ & RH 19 $(\%)$ & RH 30 (\%) & RH 39 (\%) & RH 49 (\%) \\
\hline GC-MS data $^{1}$ & & & & & \\
\hline 2-methylglyceric acid & 379 & 255 & 155 & 171 & 70 \\
2-Methyltetrols & 811 & 384 & 371 & 257 & 157 \\
2-Methylglyceric acid dimer & 308 & 68 & 0 & 0 & 0 \\
IEPOX-1 $^{\text {IEPOX-2 }}$ & 5 & 3 & 2 & 0 & 3 \\
C $_{5}$-Diol-1 & 37 & 21 & 23 & 12 & 19 \\
\hline LC-MS data $^{2}$ & 9 & 6 & 3 & 0 & 0 \\
\hline$m / z$ [M-H] $^{-}$ & & & & & \\
197 & & & & & \\
199 & 0.28 & 0.22 & 0.19 & 0.37 & 0.33 \\
211 & 3.22 & 2.46 & 3.60 & 4.66 & 4.01 \\
213 & 0.44 & 0.20 & 0.06 & 0.09 & 0 \\
215 & 2.21 & 1.87 & 1.52 & 1.48 & 0.83 \\
229 & 17.80 & 12.30 & 10.20 & 9.83 & 7.24 \\
244 & 0.70 & 0.78 & 1.11 & 1.29 & 0.83 \\
260 & 0.35 & 0.14 & 0 & 0 & 0.08 \\
274 & 0.49 & 0.35 & 0.32 & 0.28 & 0.18 \\
\hline
\end{tabular}

${ }^{1} \mathrm{MW}$ as BSTFA derivative. ${ }^{2}$ Chromatographic responses of organosulfates $\left(10^{4}\right)$.

Table 4. Estimated concentrations of reaction products $\left(\mathrm{ng} \mathrm{m}^{-3}\right)$ from the acidic photooxidation experiments (acidic seed $\left[\mathrm{H}^{+}\right]=275 \mathrm{nmol} \mathrm{m}^{-3}$ air; Lewandowski et al., 2015).

\begin{tabular}{lrrrr}
\hline & RH $8(\%)$ & RH $18(\%)$ & RH 28 (\%) & RH $44(\%)$ \\
\hline GC-MS data $^{1}$ & & & & \\
\hline 2-Methylglyceric acid & 3070 & 2136 & 982 & 473 \\
2-Methyltetrols & 5357 & 4767 & 1029 & 341 \\
2-Methylglyceric acid dimer & 90 & 144 & 102 & 43 \\
IEPOX-1 $^{\text {IEPOX-2 }}$ & 1 & 13 & 6 & 0 \\
C $_{5}$-Diol-1 & 10 & 3 & 0 & 0 \\
\hline LC-MS data $^{2}$ & 53 & 0 & 0 & 0 \\
\hline$m / z$ M-H] $^{-}$ & & & & \\
197 & & & & \\
199 & 0.88 & 0.30 & 0.21 & 0.10 \\
211 & 3.44 & 1.49 & 2.62 & 1.12 \\
213 & 1.78 & 0.50 & 0.76 & 0.48 \\
215 & 5.41 & 1.94 & 3.40 & 1.96 \\
229 & 59.00 & 18.40 & 12.30 & 3.23 \\
244 & 0.41 & 0.31 & 0.39 & 0.27 \\
260 & 4.50 & 1.16 & 0.72 & 0.42 \\
274 & 0.92 & 0.88 & 0.45 & 0.29 \\
\hline
\end{tabular}

${ }^{1}$ MW as BSTFA derivative. ${ }^{2}$ Chromatographic responses of selected main organosulfates $\left(10^{4}\right)$. 
18112

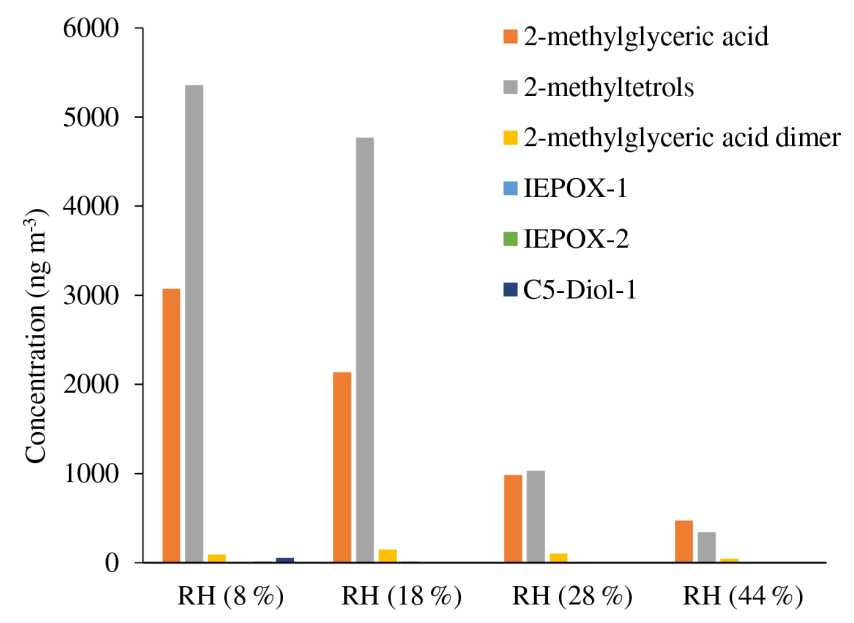

Figure 4. Concentrations of particle-phase products from the acidic-seed experiments estimated with GC-MS.

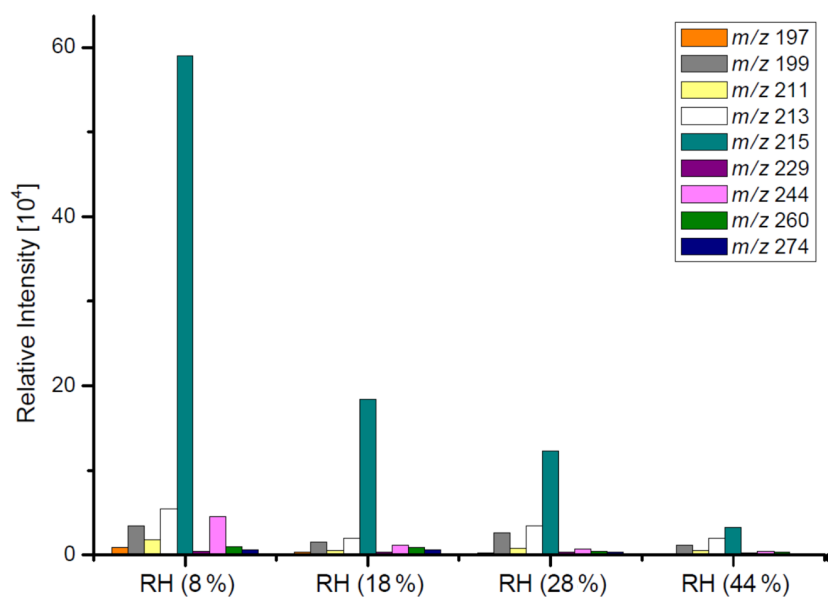

Figure 5. LC-MS chromatographic responses of OS and NOS products from the acidic-seed experiments.

same pattern. As an example, Fig. 6 shows a comparison of the concentrations of 2-methylglyceric acid under acidic and non-acidic conditions as a function of relative humidity. Acidic seed aerosol has a greater effect on 2-methylglyceric acid at lower relative humidity. Some of the compounds produced in higher quantities in the acidic-seed experiments included 2-methylglyceric acid, 2-methyltetrols, furandiolOS, 2-methyltetrol-NOS, 2-methylthreonic acid NOS, and furanone-OS, while some others in the non-acidic-seed experiments included IEPOX-2, 2-methylglyceric acid OS, and 2-methylthreonic acid OS. Yields of the remaining compounds followed an inconclusive pattern (Figs. S1, S2, and S3; Table S1 in the Supplement). Thus, this study shows that the effect of relative humidity on the formation of a wide range of isoprene SOA products cannot easily be predicted, although the majority increases with decreasing relative humidity under both acidic and non-acidic conditions.
K. Nestorowicz et al.: Chemical composition of isoprene SOA

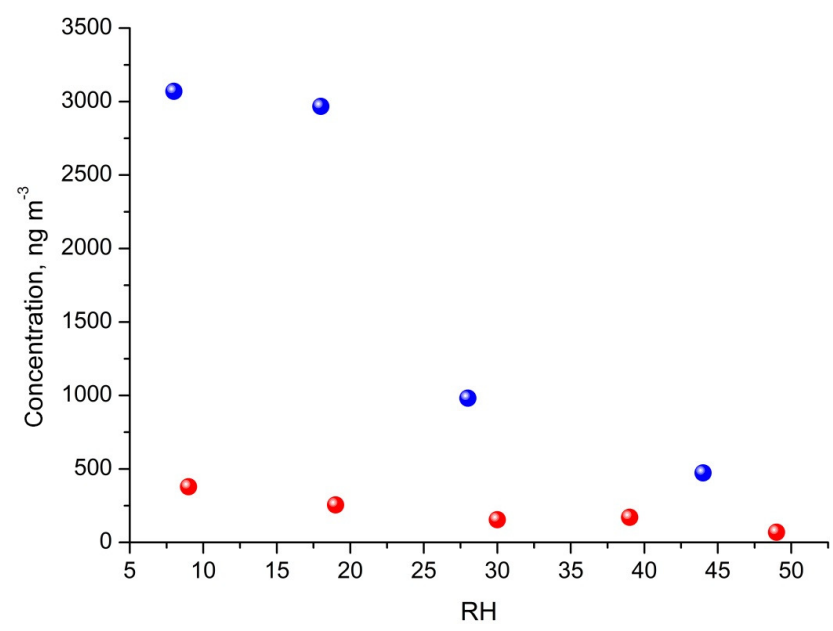

Figure 6. Influence of RH and seed acidity on the estimated concentration of 2-methylglyceric acid produced in chamber experiments with non-acidic seeds (red) and with acidic seeds (blue). See Fig. S3 for additional compounds.

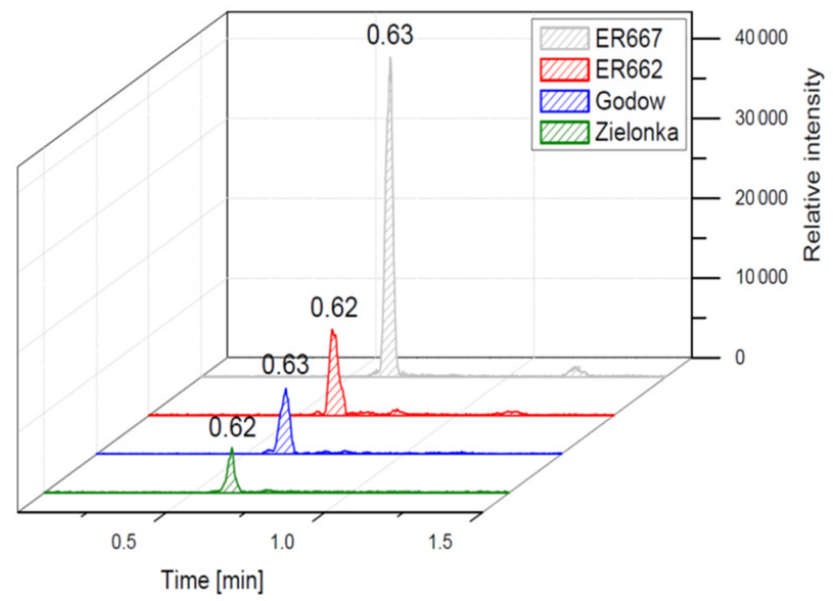

Figure 7. Extracted-ion chromatograms of 2-methylglyceric acid organosulfate with MW 200 from field studies and chamber experiments.

\subsection{Chromatographic comparison of chamber experiments and field samples}

We compared the results of chamber experiments to samples of $\mathrm{PM}_{2.5}$ collected at the two rural sites, Zielonka and Godów. To keep the experimental and ambient conditions as similar as possible, we selected the experiments carried under the highest relative humidities: ER662 at RH $44 \%$ (acidic seeds) and ER667 at RH 49\% (non-acidic seeds). Figures 7-10 show the extracted-ion chromatograms of selected components detected in the respective filter extracts. Several compounds occurred both in the chamber SOA and in the ambient samples: 2-methylglyceric acid OS (MW 200), furanetriol OS (MW 214), 2-methyltetrol OS 


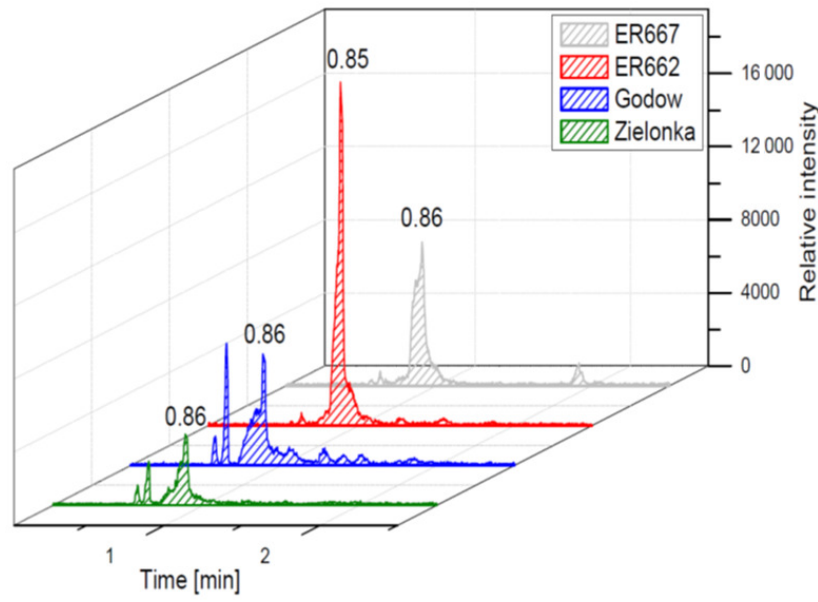

Figure 8. Extracted-ion chromatograms of furanetriol organosulfate with MW 214 from field studies and chamber experiments.

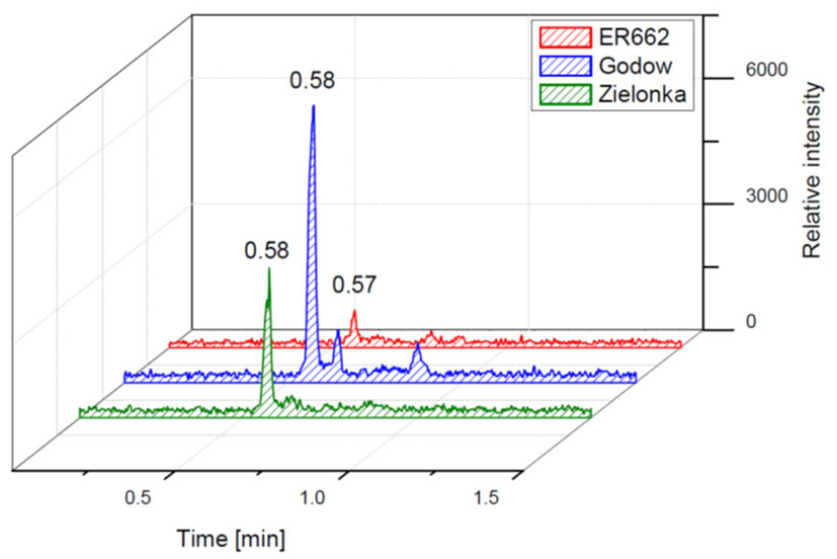

Figure 9. Extracted-ion chromatograms of 2-methyltartaric acid organosulfate with MW 244 from field studies and chamber experiments (not detected in non-acidic sample).

(MW 216), 2-methylthreonic acid OS (MW 230), and 2methylthreonic acid NOS (MW 275). The 2-methyltartaric acid OS (MW 244) was also found in ambient samples, with only trace amounts in acidic seed aerosol (Fig. 9). However, 2-methyltetrol nitrosoxy-organosulfate (MW 245) was detected in the chamber SOA (Fig. 10). The extractedion chromatograms of 2-methyltetrol nitroxy-organosulfate (MW 261) were insufficient to provide reasonable fragmentation (Fig. S4). The comparison shows that isoprene SOA in the presence of acidic seed aerosol and $\mathrm{NO}_{x}$ from the chamber studies provide a reasonable approximation of the ambient processes at both sites even though only Godów is strongly influenced by anthropogenic pollutants, mainly nitrogen oxides due to a nearby coal-fired power station. It appears that minor amounts of $\mathrm{NO}_{x}$ in the ambient atmosphere are sufficient to produce these compounds. These findings will require further confirmation.

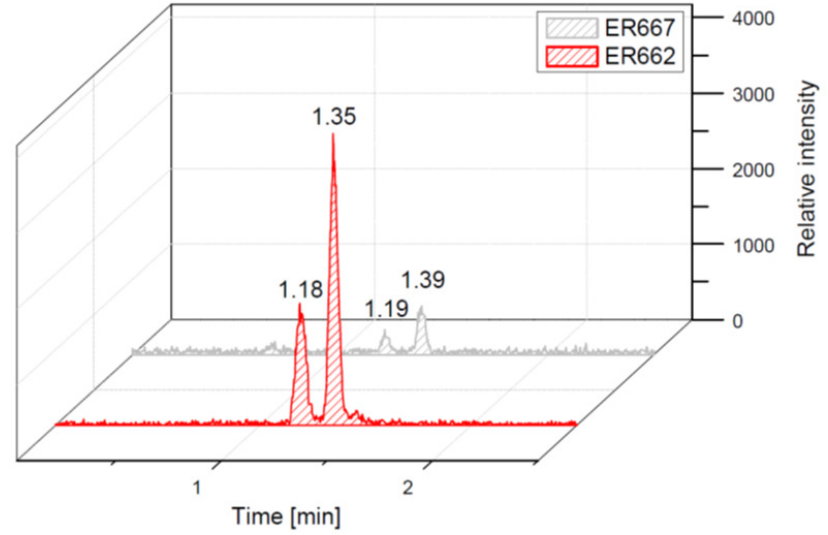

Figure 10. Extracted-ion chromatograms of nitrosoxyorganosulfate with MW 245 from chamber experiments (not detected in field samples).

\subsection{Mass spectra and proposed fragmentation pathways of newly identified organosulfates and nitroxy- and nitrosoxy-organosulfates}

Based on the high-resolution mass data and fragmentation spectra recorded for HPLC-resolved peaks, it is difficult to distinguish between isomers of the same molecular structure. Moreover, some of the peaks for selected $\mathrm{m} / \mathrm{z}$ values in the extracted-ion chromatograms may correspond to more than one compound. Therefore, identifications for the structures proposed are tentative. This ambiguity results in the fragmentation spectra having the fragment ions coming from different precursor ions with the same $m / z$. Our proposed structures for the newly identified organosulfates and nitroxyand nitrosoxy-organosulfates are based on the accurate mass measurements and the following assumptions:

- All studied compounds have the same carbon backbone of 2-methylbutane.

- The presence of the abundant $m / z 97$ peak corresponding to the $\mathrm{HSO}_{4}^{-}$ion indicates that the hydrogen atom is present at the carbon atom next to that bearing $\mathrm{HO}$ $\mathrm{SO}_{2}-\mathrm{O}-$ moiety (Attygalle et al., 2001). There are, however, exceptions seen in Figs. 11 and 12.

- When the condition given in (b) is not fulfilled, elimination of sulfur trioxide molecule from the precursor ion can be detected (Szmigielski, 2013).

- Elimination of the $\mathrm{HONO}$ and $\mathrm{HNO}_{3}$ molecules from the precursor ion is a diagnostic for the presence of the nitrous $(-\mathrm{ONO})$ and nitric $\left(-\mathrm{ONO}_{2}\right)$ esters, respectively. Similar to assumption (a), a $\beta$-hydrogen must be present to enable the $\beta$-elimination (Tovstiga et al., 2014).

The 2-methyltetrol nitroxy-organosulfate detected at $\mathrm{m} / \mathrm{z} 260$ corresponds to the major early eluting compounds 

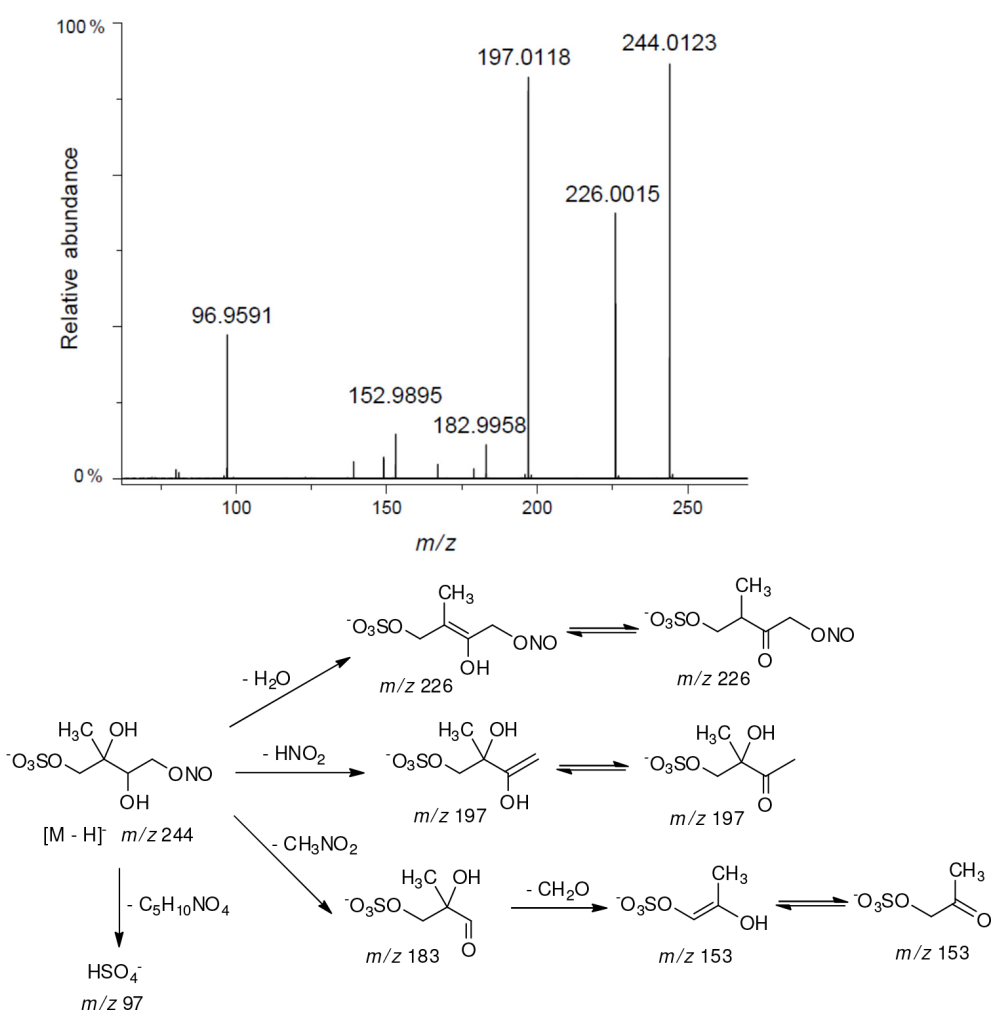

Figure 11. Electrospray product ion mass spectrum (-) of 2-methyltetrol nitrosoxy-organosulfate (MW 245) of the RT =1.35 min peak (Fig. 10) acquired for the acidic seed aerosol along with the proposed fragmentation pathway.
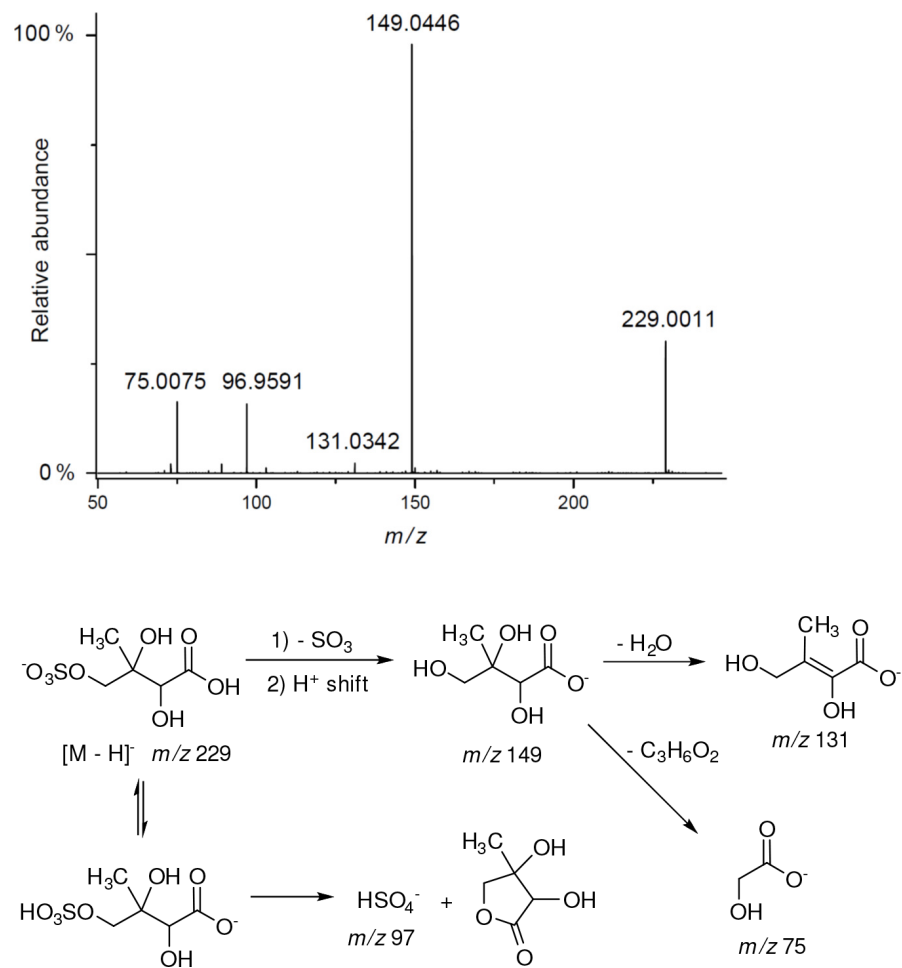

Figure 12. Electrospray product ion mass spectrum (-) of 2-methylthreonic acid organosulfate (MW 230) at RT =0.63 min (Fig. S4) acquired for Zielonka $\mathrm{PM}_{2.5}$ aerosol along with the proposed fragmentation pathway. 

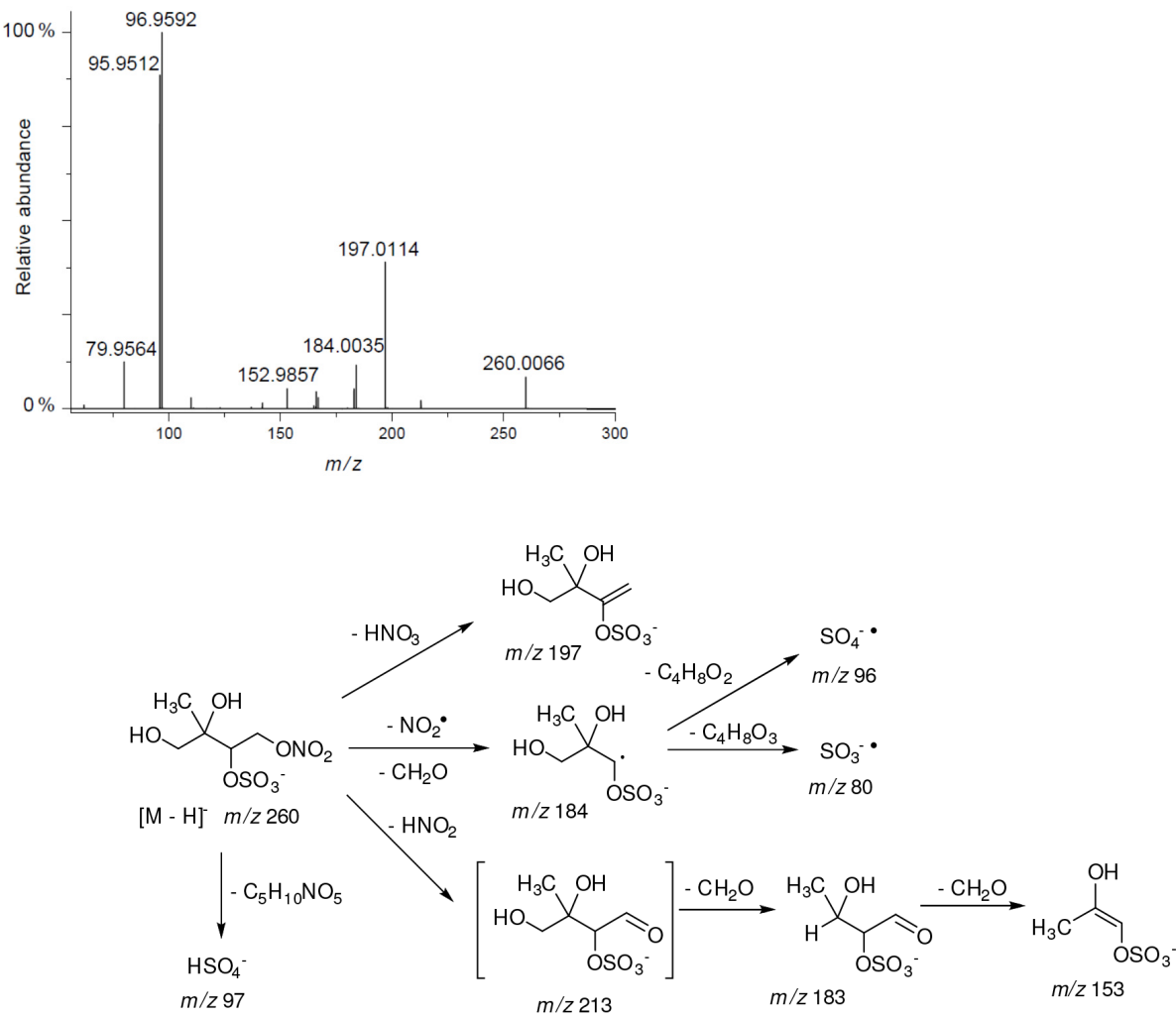

Figure 13. Electrospray product ion mass spectrum (-) of 2-methyltetrol nitroxy-organosulfate (MW 261) eluting at RT $=2.44$ min (Fig. S4) registered for the acidic seed aerosol along with proposed fragmentation pathway.
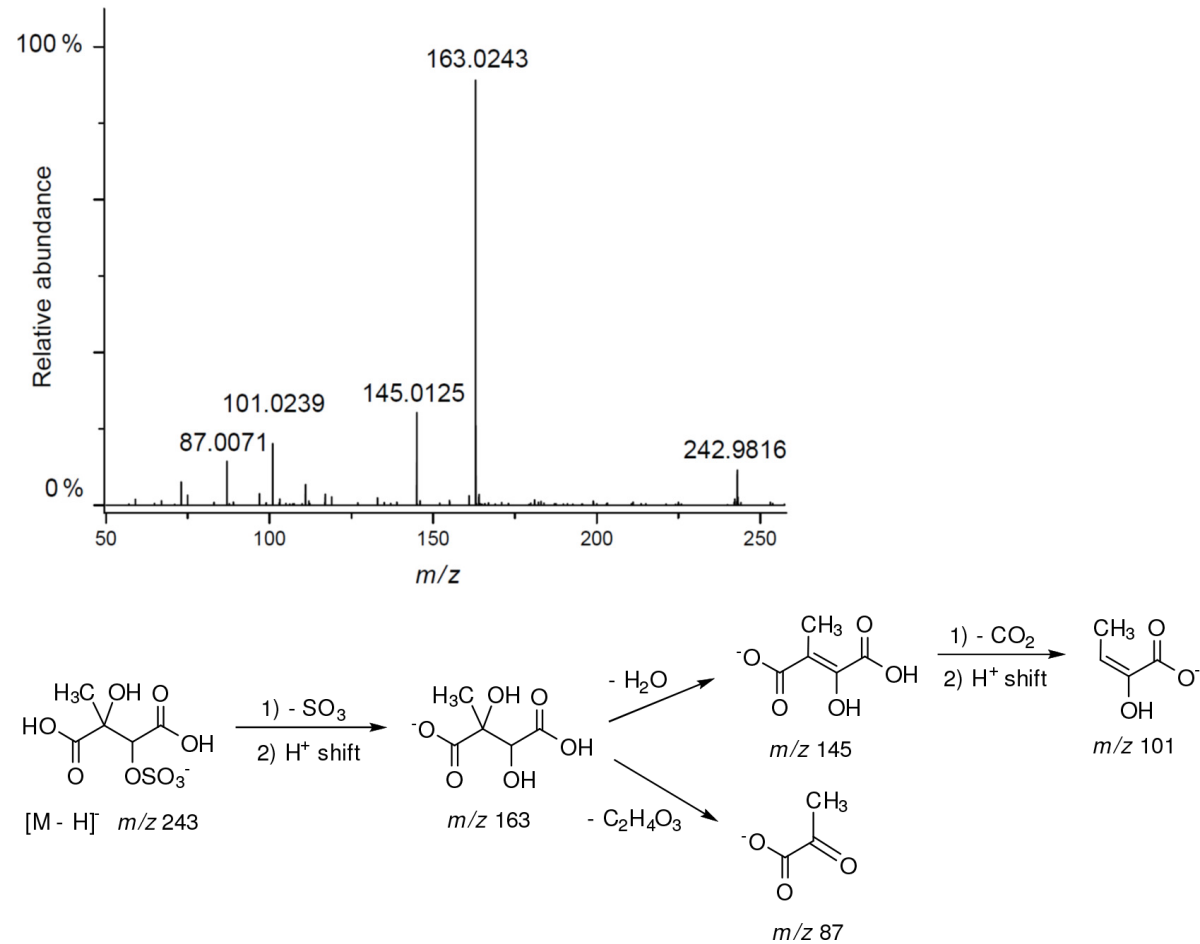

Figure 14. Electrospray product ion mass spectrum (-) of 2-methyltartaric acid organosulfate (MW 244) recorded for the RT $=0.58$ min peak (Fig. 9) from Godów fine aerosol along with the proposed fragmentation pathway. 

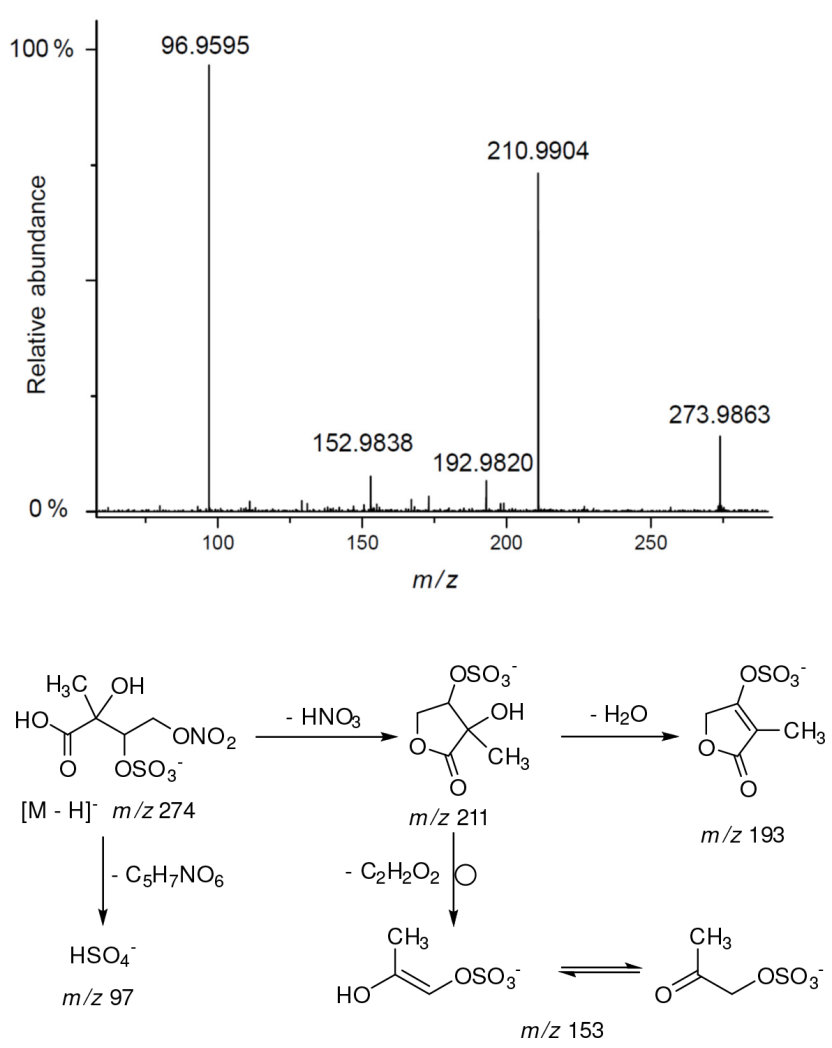

Figure 15. Electrospray product ion mass spectrum (-) of 2-methylthreonic acid nitroxy-organosulfate (MW 275) of the $\mathrm{RT}=0.83$ min peak (Fig. S4) recorded for Zielonka $\mathrm{PM}_{2.5}$ aerosol along with the proposed fragmentation pathway.

for the chamber and $\mathrm{PM}_{2.5}$ as seen in Fig. S4. The minor shifts in retention times of eluting compounds are generally due to matrix effects (Spolnik et al., 2018). Two partially resolved peaks with identical MS profiles typically indicate diastereoisomeric forms. This finding is consistent with earlier studies (Gomez-Gonzalez et al., 2008; Surratt et al., 2007a). A detailed interpretation of negative-ion electrospray mass spectra led to a proposed structure for 2-methyltetrol nitroxyorganosulfates bearing a nitroxy moiety at the primary hydroxyl group of 2-methyltetrol skeleton and sulfate group at the secondary hydroxyl group seen in Fig. 13. The main fragmentation pathways correspond to a neutral loss of $63 u$ $\left(\mathrm{HNO}_{3}\right)$, resulting in $m / z 197$ as a base peak, and to a bisulfate ion at $m / z$ 97. Another diagnostic ion at $m / z 184$ can be attributed to a combined loss of $\mathrm{NO}_{2}$ and $\mathrm{CH}_{2} \mathrm{O}$, suggesting the presence of a hydroxymethyl group in the molecule. The presence of $m / z 213$ and 183 ions supports the interpretation given above due to a characteristic neutral loss of a $\mathrm{CH}_{2} \mathrm{O}$ fragment. A revised structure for the MW 261 SOA component along with the proposed fragmentation scheme is given in Fig. 13, where only the mass spectrum of one diastereoisomer is shown.
A second abundant chamber-generated SOA component was detected at $\mathrm{m} / \mathrm{z}$ 244. In contrast to 2-methyltetrol nitroxy-organosulfate, the MW 245 unknown was not detected in $\mathrm{PM}_{2.5}$, which would suggest the compound could play a relevant role as a reactive reaction intermediate en route to particle formation through isoprene SOA chains. Two baseline-resolved peaks of identical electrospray product ion mass spectra could be attributed to diastereoisomers with an isoprene-retained backbone (Fig. 10). Surratt and co-workers observed the formation of this compound in the isoprene photooxidation experiment under high- $\mathrm{NO}_{x}$ conditions and proposed the structure to 2-methylglyceric acid nitroxy-organosulfate (Surratt et al., 2007a). However, in light of our mass spectral data we assign the MW 245 unknown to $\mathrm{C}_{5}$ organosulfate, namely 2-methyltetrol nitrosoxyorganosulfates. The $m / z, 244 \rightarrow m / z, 226$ transition in the product ion mass spectrum (Fig. 11) points to the intact secondary hydroxyl moiety of the 2-methyltetrol skeleton. The lack of $\mathrm{HNO}_{3}$ elimination from the $[\mathrm{M}-\mathrm{H}]^{-}(\mathrm{m} / \mathrm{z} 244)$ precursor ion clearly excludes the presence of the nitroxy group. However, an abundant $m / z 197$ ion, which forms through the $\mathrm{HNO}_{2}$ loss, could be associated with the existence of the -ONO residue. The structure assigned to the abundant MW 245 component from ER662 (acidic seed aerosol) along with its proposed fragmentation scheme is presented in Fig. 11.

Additional abundant SOA organosulfates were determined at $m / z 229$ and 243 for the chamber and $\mathrm{PM}_{2.5}$ as shown in Figs. 12 and 14, respectively, which do not appear to have previously been detected. The accurate mass data were recorded for the Godów sample with the following characteristics: $\mathrm{RT}=0.58 \mathrm{~min}$ in Fig. $9\left(\mathrm{C}_{5} \mathrm{H}_{7} \mathrm{O}_{9} \mathrm{~S}: 242.9816 \mathrm{Da}\right.$, error $+0.2 \mathrm{mDa}$; Fig. 14) and $\mathrm{RT}=0.63 \mathrm{~min}$ in Fig. S4 $\left(\mathrm{C}_{5} \mathrm{H}_{9} \mathrm{NO}_{8} \mathrm{~S}\right.$ : $229.0011 \mathrm{Da}$, error $+0.2 \mathrm{mDa}$; Fig. 12$)$; this suggested greater oxidation pathways for these unknown organosulfates compared to those for the formation the of sulfated-2-methyltetrols. Two partially resolved peaks of identical mass spectrometric signatures can be noted for these organosulfates, indicating the presence of two chiral centers in their molecules (Figs. 9 and S4). In either case, first eluting diastereoisomers give rise to peaks having high abundances, while the second peak is of a more minor intensity, suggesting the formation of less hindered compounds both in the chamber experiments and $\mathrm{PM}_{2.5}$. A detailed interpretation of product ion mass spectra permitted assignment of structures of the MW 244 and MW 230 unknowns to 2methyltartaric acid organosulfate and 2-methylthreonic acid organosulfate, respectively (Figs. 14 and 12 with the mass spectrum of the minor diastereoisomer not shown). Both spectra display abundant fragment ions at $m / z 163$ and 149, which could be explained by the $\mathrm{SO}_{3}$ elimination from their precursor ions. Further fragmentation of $m / z 163$ ions, i.e., a neutral loss of water followed by decarboxylation, reveals the simultaneous presence of $-\mathrm{O}-\mathrm{SO}_{3} \mathrm{H}$ and $-\mathrm{CO}_{2} \mathrm{H}$ residues in the MW 230 diastereoisomeric organosulfates. However, the absence of the bisulfate ion in the spectrum of the MW 244 
organosulfate clearly indicates a lack of a proton adjacent to the sulfated group and thus suggests the sulfation of a secondary hydroxyl group. MW 230 organosulfate and the presence of the bisulfate ion in the MS/MS spectrum does not necessarily reveal unambiguously the sulfation at a primary hydroxyl group in the molecule. The proposed fragmentation schemes for the MW 244 and 230 novel organosulfates are depicted in Figs. 14 and 12. Again, the mass spectra of related diastereoisomeric organosulfates are not presented.

A final related organosulfate was detected at $\mathrm{m} / z 274$ in substantial quantities for isoprene SOA from the chamber and rural $\mathrm{PM}_{2.5}$ (Fig. S4). To our knowledge this compound has previously not been reported. The compound has transitions of $m / z 274 \rightarrow m / z 211$ (a loss of $\mathrm{HNO}_{3}$ ) and $m / z 274 \rightarrow m / z 97$ (a loss of $\mathrm{C}_{5} \mathrm{H}_{7} \mathrm{NO}_{6}$ ) from the product ion mass spectrum from the Zielonka $\mathrm{PM}_{2.5}$ as seen in Figure 15. The high-resolution data for this organosulfate eluted at $\mathrm{RT}=0.83 \mathrm{~min}\left(\mathrm{C}_{5} \mathrm{H}_{7} \mathrm{NO}_{10} \mathrm{~S}: 273.9873 \mathrm{Da}\right.$, error $+0.4 \mathrm{mDa}$ ) clearly points to nitroxy-organosulfate from isoprene. A detailed explanation of other diagnostic ions led to a proposed structure of 2-methylthreonic acid nitroxyorganosulfate (Fig. 15). It could be assumed that due to a high oxidation state $(\mathrm{C} / \mathrm{O}=0.5)$ the MW 275 organosulfate could serves as an identifying marker of highly processed isoprene aerosol. However, further study is warranted to rationalize its formation mechanism and reactivity in the atmosphere.

While these experiments provide an analysis of a wide range of isoprene reaction products in the aerosol phase as a function of RH and acidity, they also include a number of shortcomings that need to be addressed in future work. Perhaps the most significant is the use of authentic standards to assess the contribution of these products to SOA mass at different RH. In addition, when the relative humidity is varied, it is important to measure aerosol liquid water content directly or estimated using thermodynamic models, such as ISORROPIA (Fountoukis and Nenes, 2007) or AIM (Wexler and Cregg, 2002), and other gas and particle composition (e.g., inorganic species). Liquid water inorganic species measurements were not available for this study.

The use of these marker compounds for ambient air quality models can follow the approach of Pye et al. (2013). In such an approach, the model is run using a base case chemical mechanism for isoprene, where there is no adjustment for acidity and relative humidity. A comparison can then be made with the same model having such an adjustment incorporated within the isoprene mechanism. The markers can then serve as constraints to the PM observations. For the US, the Community Multiscale Air Quality (CMAQ) model is frequently used for ozone and PM ambient concentrations (Pye et al., 2013). For Poland, a similar approach can be used with a European model having the appropriate meteorology and chemical mechanism (Miranda et al., 2015).

\section{Summary}

In this work, we have characterized several organic components from isoprene SOA, some of which have been reported in the literature. Several compounds were identified for the first time, including 2-methylthreonic acid organosulfate (MW 230), 2-methyltartaric acid organosulfate (MW 244), and 2-methyltartaric acid nitroxy-organosulfate (MW 275). The quantitative data showed the 2-methyltetrols, 2methylglyceric acid, and 2-methyltetrol organosulfates as the most abundant components of isoprene SOA. Other molecular components contributing to SOA mass were epoxydiols, mono- and dicarboxylic acids, organosulfates, and nitroxy- and nitrosoxy-organosulfates. Several organosulfates and nitroxy-organosulfates identified in chamber samples were also detected in samples of ambient aerosol collected at rural sites in Poland. Such consistency reinforces the relevance of the chamber findings although 2-methyltetrol nitrosoxy-organosulfate (MW 245) was found only in chamber experiments.

The effect of relative humidity on SOA formation was minor in the non-acidic-seed experiments and strong under acidic seed aerosol. Total SOC decreased with increasing relative humidity, but the individual components were influenced diversely. The yields of most compounds decreased, but increased levels of IEPOX-OS, 2-methylglyceric acid OS, and 2-methylthreonic acid OS were produced at medium to high relative humidity values. The acidic-seed experiments enhanced SOC production more than the non-acidic conditions under all RH conditions. However, at high humidity (44\%-49\%), the difference was relatively small. Some of the individual SOA components followed the same pattern as the SOC, while others were more abundant in non-acidic experiments or behaved in an inconsistent manner. Further research is warranted to rationalize the mechanisms of their formation in the atmosphere.

Data availability. The chromatograms, mass spectra, and data used to generate figures and tables are available at https://catalog.data. gov/harvest/epa-sciencehub (last access: 7 December 2018). For other data, please contact the corresponding authors via email at (jaoui.mohammed@epa.gov) or (ralf@ichf.edu.pl).

Supplement. The supplement related to this article is available online at: https://doi.org/10.5194/acp-18-18101-2018-supplement.

Author contributions. MJ, ML, KN, and RS designed the study; $\mathrm{KN}, \mathrm{GS}, \mathrm{MJ}$, and ML conducted experiments and analyzed the samples; KN, GS, WD, KR, MJ, RS, and ML analyzed the data and created figures and tables; all authors interpreted data and provided guidance for writing the paper; and $\mathrm{KN}, \mathrm{RS}, \mathrm{MJ}$, and TK wrote the paper. 
Competing interests. The authors declare that they have no conflict of interest.

Acknowledgements. The views expressed in this journal article are those of the author(s) and do not necessarily represent the views or policies of the U.S. Environmental Protection Agency. Mention of trade names or commercial products does not constitute endorsement or recommendation for use. The work of Polish researchers was partially supported by funds from the National Science Centre, Poland (grant no. OPUS8-2014/15/B/ST10/04276). The authors would like to thank Grzegorz Spolnik for his technical assistance during LC-MS measurements and Krzysztof Skotak for his assistance in field campaigns.

Edited by: Sergey A. Nizkorodov

Reviewed by: three anonymous referees

\section{References}

Attygalle, A., García-Rubio S., Ta J., and Meinwald J.: Collisionally-induced dissociation mass spectra of organic sulfate anions, J. Chem. Soc., Perkin Trans. 2, 498-506, 2001.

Bedini, E., Laezza, A., and Ladonisi, A.: Chemical derivatization of sulfated glycosaminoglycans, EurJOC., 18, 3018-3042, https://doi.org/10.1002/ejoc.201600108, 2016.

Bedini, E., Laezza, A., and Parrilli, M.: A review of chemical methods for the selective sulfation and desulfation of polysaccharides, Carbohydr. Polym., 174, 1224-1239, 2017.

Birch, M. E. and Cary, R. A.: Elemental carbon-based method for monitoring occupational exposures to particulate diesel exhaust, Aerosol Sci. Technol. 25, 221-224, 1996.

Black, F., Tejada, S., and Kleindienst, T.: Preparation of automobile organic emission surrogates for photochemical model validation, Atmos. Environ., 32, 2443-2451, 1998.

Budisulistiorini, S. H., Baumann, K., Edgerton, E. S., Bairai, S. T., Mueller, S., Shaw, S. L., Knipping, E. M., Gold, A., and Surratt, J. D.: Seasonal characterization of submicron aerosol chemical composition and organic aerosol sources in the southeastern United States: Atlanta, Georgia, and Look Rock, Tennessee, Atmos. Chem. Phys., 16, 5171-5189, https://doi.org/10.5194/acp16-5171-2016, 2016.

Carlton, A. G., Wiedinmyer, C., and Kroll, J. H.: A review of Secondary Organic Aerosol (SOA) formation from isoprene, Atmos. Chem. Phys., 9, 4987-5005, https://doi.org/10.5194/acp-9-49872009, 2009.

Chan, A. W. H., Chan, M. N., Surratt, J. D., Chhabra, P. S., Loza, C. L., Crounse, J. D., Yee, L. D., Flagan, R. C., Wennberg, P. O., and Seinfeld, J. H.: Role of aldehyde chemistry and $\mathrm{NO}_{x}$ concentrations in secondary organic aerosol formation, Atmos. Chem. Phys., 10, 7169-7188, https://doi.org/10.5194/acp10-7169-2010, 2010.

Claeys, M., Graham, B., Vas, G., Wang, W., Vermeylen, R., Pashynska, V., Cafmeyer, J., Guyon, P., Andreae, M. O., Artaxo, P., and Maenhaut, W.: Formation of secondary organic aerosols through photooxidation of isoprene, Science, 303, 1173-1176, 2004a.

Claeys, M., Wang, W., Ion, A. C., Kourtchev, I., Gelencser, A., and Maenhaut, W.: Formation of secondary organic aerosols from isoprene ant its gas-phase oxidation products through reaction with hydrogen peroxide, Atmos. Environ., 38, 4093-4098, 2004b.

Cui, T., Zeng, Z., dos Santos, E. O., Zhang, Z., Chen, Y., Zhang, Y., Rose, C. A., Budisulistiorini, S. H., Collins, L. B., Bodnar, W. M., de Souza, R. A. F., Martin, S. T., Machado, C. M. D., Turpin, B. T., Gold, A., Ault, A. P., and Surratt, J. D.: Development of a hydrophilic interaction liquid chromatography (HILIC) method for the chemical characterization of water-soluble isoprene epoxydiol (IEPOX)-derived secondary organic aerosol, Environ. Sci.: Processes Impacts, 20, 15241536, https://doi.org/10.1039/c8em00308d, 2018.

Czoschke, N. M., Jang, M., and Kamens, R. M.: Effect of acidic seed on biogenic secondary organic aerosol growth, Atmos. Environ., 37, 4287-4299, 2003.

Darer, A. I., Cole-Filipiak, N. C., O'Connor, A. E., and Elrod, M. J.: Formation and stability of atmospherically relevant isoprenederived organosulfates and organonitrates, Environ. Sci. Technol., 45, 1895-1902, 2011.

Dommen, J., Metzger, A., Duplissy, J., Kalberer, M., Alfarra, M. R., Gascho, A., Weingartner, E., Prevot, A. S. H., Verheggen, B., and Baltensperger, U.: Laboratory observation of oligomers in the aerosol from isoprene/ $\mathrm{NO}_{x}$ photooxidation, Geophys. Res. Lett., 33, L13805, doi:10.1029/2006GL026523, 2006.

Edney, E. O., Kleindienst, T. E., Jaoui, M., Lewandowski, M., Offenberg, J. H., Wang, W., and Claeys, M.: Formation of 2methyltetrols and 2-methylglyceric acid in secondary organic aerosol from laboratory irradiated isoprene/ $/ \mathrm{NO}_{x} / \mathrm{SO}_{2} /$ air mixtures and their detection in ambient $\mathrm{PM}_{2.5}$ samples collected in the eastern United States, Atmos. Environ., 39, 5281-5289, 2005.

Fountoukis, C. and Nenes, A.: ISORROPIA II: a computationally efficient thermodynamic equilibrium model for $\mathrm{K}^{+}$ $\mathrm{Ca}^{2+}-\mathrm{Mg}^{2+}-\mathrm{NH}_{4}^{+}-\mathrm{Na}^{+}-\mathrm{SO}_{4}^{2-}-\mathrm{NO}_{3}^{-}-\mathrm{Cl}^{-}-\mathrm{H}_{2} \mathrm{O}$ aerosols, Atmos. Chem. Phys., 7, 4639-4659, https://doi.org/10.5194/acp-74639-2007, 2007.

Froyd, K. D., Murphy, S. M., Murphy, D. M., de Gouw, J. A., Eddingsaas, N. C., and Wennberg, P. O.: Contribution of isoprenederived organosulfates to free tropospheric aerosol mass, P. Natl. Acad. Sci. USA, 107, 21360-21365, 2010.

Fu, T. M., Jacob, D. J., Wittrock, F., Burrows, J. P., Vrekoussis, M., and Henze, D. K.: Global budgets of atmospheric glyoxal and methylglyoxal, and implications for formation of secondary organic aerosols, J. Geophys. Res., D15303, doi:10.1029/2007JD009505, 2008.

Gaston, C. J., Riedel, T. P., Hang, Z., Gold., A., Surratt, J. D., and Thornton, J. A.: Reactive uptake of an isoprene-derived epoxydiol to submicron aerosol particles, Environ. Sci. Technol., 48, 11178-11186, 2014a.

Gaston, C. J., Thornton, J. A., and Ng, N. L.: Reactive uptake of $\mathrm{N}_{2} \mathrm{O}_{5}$ to internally mixed inorganic and organic particles: the role of organic carbon oxidation state and inferred organic phase separations, Atmos. Chem. Phys., 14, 5693-5707, https://doi.org/10.5194/acp-14-5693-2014, 2014b.

Goldstein, A. H. and Galbally, I. E.: Known and unexplored organic constituents in the earth's atmosphere, Environ. Sci. Technol., 41, 1514-1521, 2007.

Gomez-Gonzalez, Y., Surratt, J. D., Cuyckens, F., Szmigielski, R.,Vermeylen, R., Jaoui, M., Lewandowski, M., Offenberg, J. H., 
Kleindienst, T. E., Edney, E. O., Blockhuys, F., Van Alsenoy, C., Maenhaut, W., and Claeys, M.: Characterization of organosulfates from the photooxidation of isoprene and unsaturated fatty acids in ambient aerosol using liquid chromatography/(-) electrospray ionization mass spectrometry, J. Mass Spectrom., 43, 371-382, 2008

Guenther, A., Hewitt, C. N., Erickson, D., Fall, R., Geron, C., Graedel, T., Harley, P., Klinger, L., Lerdau, M., McKay, W. A., Pierce, T., Scholes, B., Steinbrecher, R., Tallamraju, R., Taylor, J., and Zimmerman, P.: A global model of natural volatile organic compound emissions, J. Geophys. Res., 100, 8873-8891, 1995.

Guenther, A., Hewitt, C. N., Erickson, D., Fall, R., Geron, C., Graedel, T., Harley, P., Klinger, L., Lerdau, M., McKay, W. A., Pierce, T., Scholes, B., Steinbrecher, R., Tallamraju, R., Taylor, J., and Zimmerman, P.: A global model of natural volatile organic compound emissions, J. Geophys. Res., 100, 8873-8891, 2006.

Guo, H., Xu, L., Bougiatioti, A., Cerully, K. M., Capps, S. L., Hite Jr., J. R., Carlton, A. G., Lee, S.-H., Bergin, M. H., Ng, N. L., Nenes, A., and Weber, R. J.: Fine-particle water and $\mathrm{pH}$ in the southeastern United States, Atmos. Chem. Phys., 15, 5211-5228, https://doi.org/10.5194/acp-15-5211-2015, 2015.

Hallquist, M., Wenger, J. C., Baltensperger, U., Rudich, Y., Simpson, D., Claeys, M., Dommen, J., Donahue, N. M., George, C., Goldstein, A. H., Hamilton, J. F., Herrmann, H., Hoffmann, T., Iinuma, Y., Jang, M., Jenkin, M. E., Jimenez, J. L., Kiendler-Scharr, A., Maenhaut, W., McFiggans, G., Mentel, Th. F., Monod, A., Prévôt, A. S. H., Seinfeld, J. H., Surratt, J. D., Szmigielski, R., and Wildt, J.: The formation, properties and impact of secondary organic aerosol: current and emerging issues, Atmos. Chem. Phys., 9, 5155-5236, https://doi.org/10.5194/acp9-5155-2009, 2009.

Henze, D. K. and Seinfeld, J. H.: Global secondary organic aerosol from isoprene oxidation, Geophys. Res. Lett., 33, L09812, doi:10.1029/2006GL025976, 2006.

Hettiyadura, A. P. S., Stone, E. A., Kundu, S., Baker, Z., Geddes, E., Richards, K., and Humphry, T.: Determination of atmospheric organosulfates using HILIC chromatography with MS detection, Atmos. Meas. Tech., 8, 2347-2358, https://doi.org/10.5194/amt8-2347-2015, 2015.

Hoyle, C. R., Berntsen, T., Myhre, G., and Isaksen, I. S. A.: Secondary organic aerosol in the global aerosol - chemical transport model Oslo CTM2, Atmos. Chem. Phys., 7, 5675-5694, https://doi.org/10.5194/acp-7-5675-2007, 2007.

Isaacman-VanWertz, G., Yee, L. D., Kreisberg, N. M., Wernis, R., Moss, J. A., Hering, S. V., de Sá, S. S., Martin, S. T., Alexander, M. L., Palm, B. B., Hu, W., Campuzano-Jost, P., Day, D. A., Jimenez, J. L., Riva, M., Surratt, J. D., Viegas, J., Manzi, A., Edgerton, E., Baumann, K., Souza, R., Artaxo, P., and Goldstein, A. H.: Ambient gas-particle partitioning of tracers for biogenic oxidation, Environ. Sci. Technol., 50, 9952-9962, 2016.

Jang, M., Czoschke, N. M., Lee, S., and Kamens, R. M.: Heterogeneous atmospheric aerosol production by acid-catalyzed particlephase reactions, Science, 298, 814-817, 2002.

Jaoui, M., Kleindienst, T. E., Lewandowski, M., and Edney, E. O.: Identification and quantification of aerosol polar oxygenated compounds bearing carboxylic or hydroxyl groups, 1. Method development, Anal. Chem., 76, 4765-4778, 2004.

Jaoui, M., Corse, E. W., Lewandowski, M., Offenberg, J. H., Kleindienst, T. E., and Edney, E. O.: Formation of organic tracers from isoprene SOA under acidic conditions, Atmos. Environ., 44, 1798-1805, 2010.

Kleindienst, T. E., Edney, E. O., Lewandowski, M., Offenberg, J. H., and Jaoui, M.: Secondary organic carbon and aerosol yields from the irradiations of isoprene and $\alpha$-pinene in the presence of $\mathrm{NO}_{x}$ and $\mathrm{SO}_{2}$, Environ. Sci. Technol., 40, 3807-3812, 2006.

Kleindienst, T. E., Jaoui, M., Lewandowski, M., Offenberg, J. H., Lewis, C. W., Bhave, P. V., and Edney, E. O.: Estimates of the contributions of biogenic and anthropogenic hydrocarbons to secondary organic aerosol at a southeastern US location, Atmos. Environ., 41, 37, 8288-8300, 2007.

Kleindienst, T. E., Lewandowski, M., Offenberg, J. H., Jaoui, M., and Edney, E. O.: The formation of secondary organic aerosol from the isoprene $+\mathrm{OH}$ reaction in the absence of $\mathrm{NO}_{x}$, Atmos. Chem. Phys., 9, 6541-6558, https://doi.org/10.5194/acp-9-65412009, 2009.

Kolender, A. A. and Matulewicz, M. C.: Desulfation of sulfated galactans with chlorotrimethylsilane. Characterization of b-carrageenan by ${ }^{1} \mathrm{H}$ NMR spectroscopy, Carbohydr. Res., 339, 1619-1629, 2004.

Kristensen, K., Bilde, M., Aalto, P. P., Petaja, T., and Glasius, M.: Denuder/filter sampling of organic acids and organosulfates at urban and boreal forest sites: Gas/particle distribution and possible sampling artefacts, Atmos. Environ., 45, 4546-4556, 2011.

Kroll, J. H., Ng, N. L., Murphy, S. M., Flagan, R. C., and Seinfeld, J. H.: Secondary organic aerosol formation from isoprene photooxidation, Environ. Sci. Technol., 40, 1869-1877, 2006.

Lewandowski, M., Jaoui, M., Offenberg, J. H., Krug, J. D., and Kleindienst, T. E.: Atmospheric oxidation of isoprene and 1,3butadiene: influence of aerosol acidity and relative humidity on secondary organic aerosol, Atmos. Chem. Phys., 15, 3773-3783, https://doi.org/10.5194/acp-15-3773-2015, 2015.

Lin, Y.-H., Zhang, Z., Docherty, K. S., Zhang, H., Budisulistiorini, S. H., Rubitschun, C. L., Shaw, S. L., Knipping, E. M., Edgerton, E. S., Kleindienst, T. E., Gold, A., and Surratt, J. D.: Isoprene Epoxydiols as Precursors to Secondary Organic Aerosol Formation: Acid-Catalyzed Reactive Uptake Studies with Authentic Compounds, Environ. Sci. Technol., 3, 250-258, 2012.

Lin, Y.-H., Knipping, E. M., Edgerton, E. S., Shaw, S. L., and Surratt, J. D.: Investigating the influences of $\mathrm{SO}_{2}$ and $\mathrm{NH}_{3}$ levels on isoprene-derived secondary organic aerosol formation using conditional sampling approaches, Atmos. Chem. Phys., 13, 84578470, https://doi.org/10.5194/acp-13-8457-2013, 2013.

Lin, Y. H., Budisulistiorini, S. H., Chu, K., Siejack, R. A., Zhang, H., Riva, M., Zhang, Z., Gold, A., Kautzman, K. E., and Surratt, J. D.: Light-Absorbing Oligomer Formation in Secondary Organic Aerosol from Reactive Uptake of Isoprene Epoxydiols. Environ. Sci. Technol., 48, 12012-12021, 2014.

Marais, E. A., Jacob, D. J., Jimenez, J. L., Campuzano-Jost, P., Day, D. A., Hu, W., Krechmer, J., Zhu, L., Kim, P. S., Miller, C. C., Fisher, J. A., Travis, K., Yu, K., Hanisco, T. F., Wolfe, G. M., Arkinson, H. L., Pye, H. O. T., Froyd, K. D., Liao, J., and McNeill, V. F.: Aqueous-phase mechanism for secondary organic aerosol formation from isoprene: application to the southeast United States and co-benefit of $\mathrm{SO}_{2}$ emission controls, Atmos. Chem. Phys., 16, 1603-1618, 2016.

Mingjie, X., Hannigan, M. P., and Barsanti, K. C.: Gas/Particle Partitioning of 2-Methyltetrols and Levoglucosan at an Urban Site in Denver, Environ. Sci. Technol., 48, 2835-2842, 2014. 
Miranda, A., Silveira, C., Ferreira, J., Montheiro, A., Lopes, D., Relvas, H., Borrego, C., and Roebeling, P.: Current air quality plans in Europe designed to support air quality management policies, Atmos. Pollut. Res., 6, 434-443, 2015.

Nguyen, T. B., Roach, P. J., Laskin, J., Laskin, A., and Nizkorodov, S. A.: Effect of humidity on the composition of isoprene photooxidation secondary organic aerosol, Atmos. Chem. Phys., 11, 6931-6944, https://doi.org/10.5194/acp-11-6931-2011, 2011.

Noziere, B., Ekstrom, S., Alsberg, T., and Holmstrom, S.: Radical-initiated formation of organosulfates and surfactants in atmospheric aerosol, Geophys. Res. Lett., 37, L0580, doi:10.1029/2009GL041683, 2010.

Nguyen, Q. T., Christensen, M. K., Cozzi, F., Zare, A., Hansen, A. M. K., Kristensen, K., Tulinius, T. E., Madsen, H. H., Christensen, J. H., Brandt, J., Massling, A., Nøjgaard, J. K., and Glasius, M.: Understanding the anthropogenic influence on formation of biogenic secondary organic aerosols in Denmark via analysis of organosulfates and related oxidation products, Atmos. Chem. Phys., 14, 8961-8981, https://doi.org/10.5194/acp14-8961-2014, 2014.

Nguyen, T. B., Bates, K. H., Crounse, J. D., Schwantes, R. H., Zhang, X., Kjaergaard, H. G., Surratt, J. D., Lin, P., Laskin, A., Seinfeld, J. H., and Wennberg, P. O.: Mechanism of the hydroxyl radical oxidation of methacryloyl peroxynitrate (MPAN) and its pathway toward secondary organic aerosol formation in the atmosphere, Phys. Chem. Chem. Phys., 17, 17914-17926, 2015.

Offenberg, J. H., Lewandowski, M., Edney, E. O., Kleindienst, T. E., and Jaoui, M.: Influence of aerosol acidity on the formation of secondary organic aerosol from biogenic precursors hydrocarbons, Environ. Sci. Technol., 43, 7142-7147, 2009.

Perri, M. J., Lim, Y. B., Seitzinger, S. P., and Turpin, B. J.: Organosulfates from glycolaldehyde in aqueous aerosols and clouds: Laboratory studies, Atmos. Environ., 44, 2658-2664, 2010.

Poulain, L., Wu, Z., Petters, M. D., Wex, H., Hallbauer, E., Wehner, B., Massling, A., Kreidenweis, S. M., and Stratmann, F.: Towards closing the gap between hygroscopic growth and CCN activation for secondary organic aerosols - Part 3: Influence of the chemical composition on the hygroscopic properties and volatile fractions of aerosols, Atmos. Chem. Phys., 10, 37753785, https://doi.org/10.5194/acp-10-3775-2010, 2010.

Paulot, F., Crounse, J. D., Kjaergaard, H. G., Kurten, A., St. Clair, J. M., Seinfeld, J. H., and Wennberg, P. O.: Unexpected epoxide formation in the gas-phase photooxidation of isoprene, Science, 325, 730-733, 2009.

Pye, H. O. T., Pinder, R. W., Piletic, I. R., Xie, Y., Capps, S. L., Lin, Y.-H., Surratt, J. D., Zhang, Z., Gold, A., Luecken, D. J., Hutzell, W. T., Jaoui, M., Offenberg, J. H., Kleindienst, T. E., Lewandowski, M., and Edney, E. O.: Epoxide Pathways Improve Model Predictions of Isoprene Markers and Reveal Key Role of Acidity in Aerosol Formation, Environ. Sci. Technol. Lett., 2, 38-42, 2013.

Rattanavaraha, W., Chu, K., Budisulistiorini, S. H., Riva, M., Lin, Y.-H., Edgerton, E. S., Baumann, K., Shaw, S. L., Guo, H., King, L., Weber, R. J., Neff, M. E., Stone, E. A., Offenberg, J. H., Zhang, Z., Gold, A., and Surratt, J. D.: Assessing the impact of anthropogenic pollution on isoprene-derived secondary organic aerosol formation in $\mathrm{PM}_{2.5}$ collected from the Birmingham, Alabama, ground site during the 2013 Southern Oxi- dant and Aerosol Study, Atmos. Chem. Phys., 16, 4897-4914, https://doi.org/10.5194/acp-16-4897-2016, 2016.

Riedel, T. P., Lin, Y., Budisulistiorini, S. H., Gaston, C. J., Thornton, J. A., Zhang, Z., Vizuete, W., Gold, A., and Surratt, J. D.: Heterogeneous reactions of isoprene-derived epoxides: reaction probabilities and molar secondary organic aerosol yield estimates, Environ. Sci. Technol. Lett., 2, 38-42, 2015.

Riva, M., Budisulistiorini, S. H., Zhang, Z., Gold, A., and Surratt, J. D.: Chemical characterization of secondary organic aerosol constituents from isoprene ozonolysis in the presence of acidic aerosol, Atmos. Environ., 130, 5-13, 2016.

Riva, M. P., Budisulistiorinia, S. H., Zhang, Z., Golda, A., Thornton, J. A., Turpin, B. J., and Surratt, J. D.: Multiphase reactivity of gaseous hydroperoxide oligomers produced from isoprene ozonolysis in the presence of acidified aerosols, Atmos. Environ., 152, 314-322, 2017.

Rudzinski, K. J.: Heterogeneous and Aqueous-Phase Transformations of Isoprene, in: Environmental Simulation Chambers: Application to Atmospheric Chemical Processes, Springer, ISBN: 978-1-4020-4230-0, 261-277, 2004.

Rudzinski, K. J., Gmachowski, L., and Kuznietsova, I.: Reactions of isoprene and sulphoxy radical-anions - a possible source of atmospheric organosulphites and organosulphates, Atmos. Chem. Phys., 9, 2129-2140, https://doi.org/10.5194/acp-9-2129-2009, 2009.

Rudzinski, K. J., Szmigielski, R., Kuznietsova, I., Wach, P., and Staszek, D.: Aqueous-phase story of isoprene - A mini-review and reaction with HONO, Atmos. Environ., 130, 163-171, 2016.

Schindelka, J., Iinuma, Y., Hoffmann, D., and Herrmann, H.: Sulfate radical-initiated formation of isoprene-derived organosulfates in atmospheric aerosols, Faraday Discuss., 165, 237-259, 2013.

Shalamzari, M. S., Ryabtsova, O., Kahnt, A., Vermeylen, R., Herent, M. F., Quentin-Leclercq, J., Van de Veken, P., Maenhaut, W. and Claeys, M.: Mass spectrometric characterization of organosulfates related to secondary organic aerosol from isoprene, Rapid Commun. Mass Spectrom., 27, 784-794, doi:10.1002/rcm.6511, 2013.

Shalamzari, M. S., Vermeylen, R., Blockhuys, F., Kleindienst, T. E., Lewandowski, M., Szmigielski, R., Rudzinski, K. J., Spólnik, G., Danikiewicz, W., Maenhaut, W., and Claeys, M.: Characterization of polar organosulfates in secondary organic aerosol from the unsaturated aldehydes 2-E-pentenal, 2- $E$ hexenal, and 3-Z-hexenal, Atmos. Chem. Phys., 16, 7135-7148, https://doi.org/10.5194/acp-16-7135-2016, 2016.

Spolnik, G., Wach, P., Rudzinski, K. J., Skotak, K., Danikiewicz, W., and Szmigielski, R.: Improved UHPLC-MS/MS Methods for Analysis of Isoprene-Derived Organosulfates, Anal. Chem., 90, 3416-3423, 2018.

Stone, E. A., Yang, L., Yu, L. E., and Rupakheti, M.: Characterization of organosulfates in atmospheric aerosols at four Asian locations, Atmos. Environ., 47, 323-329, 2012.

Surratt, J. D., Murphy, S. M., Kroll, J. H., Ng, N. L., Hildebrandt, L., Sorooshian, A., Szmigielski, R., Vermeylen, R., Maenhaut, W., Claeys, M., Flagan, R. C., and Seinfeld, J. H.: Chemical composition of secondary organic aerosol formed from the photooxidation of isoprene, J. Phys. Chem. A, 110, 9665-9690, 2006.

Surratt, J. D., Kroll, J. H., Kleindienst, T. E., Claeys, M., Sorooshian, A., Ng, N. L., Offenberg, J. H., Lewandowski, M., Jaoui, M., Flagan, R. C., and Seinfeld, J. H.: Evidence for 
organosulfates in secondary organic aerosol, Environ. Sci. Technol., 41, 517-527, 2007a.

Surratt, J. D., Lewandowski, M., Offenberg, J. H., Jaoui, M., Kleindienst, T. E., Edney, E. O., and Seinfeld, J. H.: Effect of acidity on secondary organic aerosol formation from isoprene, Environ. Sci. Technol., 41, 5363-5369, 2007b.

Surratt, J. D., Gomez-Gonzalez, Y., Chan, A. W. H., Vermeylen, R., Shahgholi, M., Kleindienst, T. E., Edney, E. O., Offenberg, J. H., Lewandowski, M., Jaoui, M., Maenhaut, W., Claeys, M., Flagan, R. C., and Seinfeld, J. H.: Organic sulfate formation in biogenic secondary organic aerosol, J. Phys. Chem., 112, 83458378, 2008.

Surratt, J. D., Chan, A. W. H., Eddingsaas, N. C., Chan, M., Loza, C. L., Kwan, A. J., Hersey, S. P., Flagan, R. C., Wennberg, P. O., and Seinfeld, J. H.: Reactive intermediates revealed in secondary organic aerosol formation from isoprene, P. Natl. Acad. Sci. USA, 107, 6640-6645, 2010.

Szmigielski, R., Vermeylen, R., Dommen, J., Metzger, A., Maenhaut, W., Claeys, M. and Baltensperger, U.: The acid effect in the formation of 2-methyltetrols from the photooxidation of isoprene in the presence of $\mathrm{NO}_{x}$, Atmos. Res., 98, 183-189, 2010.

Szmigielski, R.: The chemistry of organosulfates and organonitrates, in: Disposal of dangerous chemicals in urban areas and mega cities: role of oxides and acids of nitrogen in atmospheric chemistry, edited by: Barnes, I. and Rudzinski, K. J., Springer, ISBN 978-94-007-5036-4, 211-226, 2013.

Szmigielski, R.: Evidence for $\mathrm{C}_{5}$ organosulfur secondary organic aerosol components from in-cloud processing of isoprene: Role of reactive $\mathrm{SO}_{4}$ and $\mathrm{SO}_{3}$ radicals, Atmos. Environ., 130, 14-22, 2016.

Takano, R., Matsuo, M., Kamei-Hayashi, K., Hara, S., and Hirase, S. A.: Novel regioselective desulfation method specific to carbohydrate 6-sulfate using silylation reagents, Biosci. Biotech. Biochem., 56, 1577-1580, 1992.

Tolocka, M. P. and Turpin, B.: Contribution of organosulfur compounds to organic aerosol mass, Environ. Sci. Technol., 46, 7978-7983, 2012.
Tovstiga, T. E., Gillis, E. A., Grossert, S., and White, R. L.: Characterization of multiple fragmentation pathways initiated by collision-induced dissociation of multifunctional anions formed by deprotonation of 2-nitrobenzenesulfonylglycine, J. Mass Spectrom., 49, 168-177, 2014.

Wang, W., Kourtchev, I., Graham, B., Cafmeyer, J., Maenhaut, and Wand Claeys, M.: Characterization of oxygenated derivatives of isoprene related to 2-methyltetrols in Amazonian aerosols using trimethylsilylation and gas chromatography/ion trap mass spectrometry, Rapid Commun. Mass Spectrom., 19, 1343-1351, 2005.

Wexler, A. S. and Clegg, S. L.: Atmospheric aerosol models for systems including the ions $\mathrm{H}^{+}, \mathrm{NH}_{4}^{+}, \mathrm{Na}^{+}, \mathrm{SO}_{4}^{2-}$, $\mathrm{NO}_{3}^{-}, \mathrm{Cl}^{-}, \mathrm{Br}^{-}$, and $\mathrm{H}_{2} \mathrm{O}$, J. Geophys. Res., 107, 4207, https://doi.org/10.1029/2001JD000451, 2002.

Wong, J. P. S., Lee, A. K. Y., and Abbatt J. P. D.: Impacts of Sulfate Seed Acidity and Water Content on Isoprene Secondary Organic Aerosol Formation, Environ. Sci. Technol., 49, 13215-13221, 2015.

Vasconcelos, L. A., Macias, E. S., and White, W. H.: Aerosol composition as a function of haze and humidity levels in the Southwestern US, Atmos. Environ., 28, 3679-3691, 1994.

Xie, M., Hannigan, M. P., and Barsanti, K. C.: Gas/Particle Partitioning of 2-Methyltetrols and Levoglucosan at an Urban Site in Denver, Environ. Sci. Technol., 48, 2835-2842, 2014.

Zhang, H., Surratt, J. D., Lin, Y. H., Bapat, J., and Kamens, R. M.: Effect of relative humidity on SOA formation from isoprene/NO photooxidation: enhancement of 2-methylglyceric acid and its corresponding oligoesters under dry conditions, Atmos. Chem. Phys., 11, 6411-6424, https://doi.org/10.5194/acp11-6411-2011, 2011.

Zhang, Y., Chen, Y., Lambe, A. T., Olson, N. E., Lei, Z., Craig, R. L., Zhang, Z., Gold, A., Onasch, T. B., Jayne, J. T., Worsnop, D. R., Gaston, C. J., Thornton, J. A., Vizuete, W., Ault, A. P., and Surratt, J. D.: Effect of the Aerosol-Phase State on Secondary Organic Aerosol Formation from the Reactive Uptake of IsopreneDerived Epoxydiols (IEPOX), Environ. Sci. Technol. Lett., 5, 167-174, 2018. 